\title{
Binbaşı Hüseyin Rauf (Orbay) Müfrezesi'nin Faaliyetlerinin Modern Gayrinizami Harp Teorisi Açısından Değerlendirilmesi *
}

Zeynel LEVENT **

Öz

\begin{abstract}
Literatürde, teşkiline I. Dünya Harbi’nin ilk günlerinde başlanılan ve Afganistan üzerinden Hindistan’a ulaşarak, İngiltere'yi can evinden vurmayı amaçlayan Binbaşı Hüseyin Rauf (Orbay) Müfrezesi’nin faaliyetlerini konu alan akademik çalışmalar görmek mümkündür. Ancak, ortak noktaları konuyu klasik askeri tarih yaklaşımıyla ele almak olan bu çalışmalar ile müfrezenin yüklendiği misyonun ve harbin neticesine olan etkisinin tam anlamıyla anlaşılması mümkün değildir. Bu durum, sıradışı yöntemlerle mücadele etmek üzere kurgulanan müfrezenin faaliyetlerinin anlamlandırılabilmesi adına modern gayrinizami harp teorisinin kullanılmasını zorunlu kılmaktadır. Nitekim konuya gayrinizami harp penceresinden bakıldığında, her yönüyle konvansiyonel bir birlikten ayrışan bu müfrezenin ilk teşkil amacı olan Afganistan ve Hindistan’a ulaşamamış olmakla birlikte, İran'daki faaliyetleriyle harbin seyrini büyük oranda etkilediği görülecektir.
\end{abstract}

Arşiv belgeleri, dönemin tanıklarına ait hatıralar ve ulusal/uluslararası literatüre girmiş Türkçe, İngilizce, Almanca eserler üzerinden yapılan çapraz okumaların, modern gayrinizami harp konseptinin oluşumuna katkı sağlayan teorisyenlerin çalışmalarıyla harmanlanması sonucunda ortaya çıkan bu çalışmayla müfrezenin faaliyetlerine yeni bir boyut kazandırılması ve literatürdeki eksikliğin giderilmesine katkı sağlanması amaçlanmaktadır.

Anahtar Kelimeler: Birleşik Harekât, Gayrinizami Harp, Panislamizm, Psikolojik Harp, Teşkilât-1 Mahsusa.

\section{Evaluation of the Activities of the Detachment of the Major Hiiseyin Rauf (Orbay) in Accordance with the Modern Unconventional Warfare Theory}

\begin{abstract}
In this literature, it is possible to see the academic studies on the activities of the Major Hüseyin Rauf's (Orbay) Detachment which hard the aim of striking home of England by reaching India over Afghanistan in the first days of the 1st World War. However, with these studies that have the common point of taking the subject from the military historical approach. It is impossible to understand the mission that the detachment put on and the effect to the result of the war.As a matter of fact, when we look at the issue from the framework of the unconventional warfare, it'll be seen that this detachment, which was seperated from a conventional unit in every aspect, couldn't reach Afghanistan and India
\end{abstract}

\footnotetext{
*-Bu çalışma, “Teşkilât-ı Mahsusa'dan Kuva-yı Milliye'ye Gayrinizami Harp (1913-1922)” adlı doktora tezinden üretilmiştir.

**-Doktor, araştırmacı-yazar, e-posta: zeynellevent01@gmail.comＯRCID ID: 0000-0002-6814-6247
} 
which was the first purpose of the formation, but it hand a great influence on the course of the war with its activities in Iran.

\begin{abstract}
The aim of this study is to create a new dimension to the activities of the detachment and to contribute to the correction of the deficiency in the literature by means of the studies of the theorists who contributed to the modern unconventioal warfare concept by combining the archival documents, memories of the witnesses of the period, and cross-readings made in Turkish, English and German studies that entered into national/international literature.
\end{abstract}

Key Words: Combined Operation, Unconventional Warfare, Panislamism, Psychological Warfare, The Ottoman Special Organization.

\title{
GíRIş
}

Sona ermesinin üzerinden yüz yıl geçmiş olmasına rağmen, hâlâ akılları kurcalayan “Osmanlı Devleti I. Dünya Harbi'ne girmese, ne olurdu?" sorusuna verilebilecek en isabetli yanıt, içinde bulunulan şartlar gereği Osmanlı Devleti’nin harbin dışında kalmasının mümkün olmadığıdır. ${ }^{3}$

Dönemin şartlarının dayatmasıyla 2 Ağustos 1914 tarihinde imzalanan Türk-Alman İttifak Antlaşmasını ${ }^{4}$ takiben 3 Ağustos 1914 tarihinde seferberlik çağrısı yapan Osmanlı Devleti ${ }^{5}$ Kafkas (Doğu), Irak, Filistin-Suriye, Çanakkale, Galiçya, Makedonya, Romanya, YemenHicaz, İran ve Libya olmak üzere on ayrı cephede dört yıl sürecek bir mücadele içine girmiştir. ${ }^{6} 550$ bin kişinin şehit olduğu, 2 milyon kişinin yaralandığ 1 ve bunların yaklaşık 900 bininin evlerine sakat olarak döndükleri, harp masraflarınınise 1918 yılında 325 milyon Osmanlı lirasına ulaştığı ${ }^{7}$ bu büyük harpte Alman Genelkurmayı’nın Osmanlı ordusundan beklentilerini Alman general Otto Liman von Sanders; boğazları savunmak, geniş hudutlarını korumakla kalmayıp Mısır’ı zaptetmek, İran’ bağımsızlı̆̆ına kavuşturmak, Kafkasyada bağımsız devletlerin ortaya çıkmasına destek vermek, Afganistan üzerinden Hindistan'ı tehdit etmek ve ayaklanmalar çıkarmak, Avrupa cephelerindeki mücadelede müttefiklerine yardım etmek, olarak sıralamaktadır. ${ }^{8}$

3- Akdes Nimet Kurat, Türkiye ve Rusya: XVII. Yüzyıl Sonundan Kurtuluş Savaşına Kadar Türk-Rus Illişkileri (1798-1919), Türk Tarih Kurumu Yayınları, Ankara, 2011, s. 228-229; Şükrü Tezer, Atatürk'ün Hatıra Defteri, Türk Tarih Kurumu Yayınları, Ankara, 1995, s. 101; Masayuki Yamauchi, Hoşnut Olamamış Adam-Enver Paşa Türkiye'den Türkistan 'a, Bağlam Yayınları, İstanbul, 1995, s. 283.

4- Carl Mühlmann, İmparatorluğun Sonu 1914: Osmanlı Savaşa Neden ve Nasıl Girdi?, Çev: Kadir Kon, Timaş Yayınları, İstanbul, 2009, s. 81-84.

5- Mustafa Ragıp Esatl1, İttihat ve Terakki, Hürriyet Yayınları, İstanbul, 1956, s. 257-258.

6- İsmet Görgülü, On Yıllık Harbin Kadrosu, Türk Tarih Kurumu Yayınları, Ankara, 1993, s. 51-52.

7- Tarık Zafer Tunaya, Türkiye'de Siyasal Partiler: Ittihat ve Terakki, Bir Çağın, Bir Kuşağın, Bir Partinin Tarihi, Cilt: 3, İletişim Yayınları, İstanbul, 2015, s. 628-629.

8- Liman von Sanders, Fünf Jahre Türkei (Mit zahlreichen Textskizzen und drei katren beliagen), Verlag Von August Scherl, Berlin, 1920, p. 407-408. 
$\mathrm{Bu}$ hedefler arasında en çok dikkat çeken Hindistan’a yönelik girişimlerdir. Nitekim Almanların 20'nci yüzyılın alâmet-i farikasını, renkli ırkların Avrupa'daki müstemleke imparatorluklarına karşı kıyamı olarak gören Mareşal Goltz gibi birçok Alman yönetici İngiltere'yi can evinden vurmanın yolunun Hindistan'daki İngiliz egemenliğine son vermekten geçtiği kanaatini taşımaktadır. ${ }^{9}$

Alman Genelkurmayı’nın üzerinde yoğunlaştığı Hindistan’a yönelik girişimlerin erken dönem uygulamalarının başında akademisyen Vahdet Keleşyılmazın, Türk-Alman ittifakı ve Hintli istiklâlcilerce tasavvur olunan bağımsızlık hareketi kuvveden fiile çıkmış olsaydı, Bolşevik devrimi ya da Amerika’nın harbe müdahalesi kadar önemli bir etki yaratırdı, sözleriyle tasvir ettiği Binbaşı Hüseyin Rauf (Orbay) Müfrezesi'nin faaliyetleri gelmektedir. ${ }^{10}$

\section{BİNBAŞI HÜSEYİN RAUF (ORBAY) MÜFREZESI'NİN TEŞKİLİ VE FAALIYETLERİ}

Bahse konu müfrezenin teşkil fikrinin kime ait olduğu ve amacı konusunda ulusal ve uluslararası literatürde tam bir mutabakat sağlanmış değildir. Mehmet Saray’a göre; I. Dünya Harbi’nin başlaması ve Almanya ile Osmanlı Devleti’nin müştereken, Rusya ile İngiltere’ye harp ilanı haberinin yayılması Hindistan, Afganistan ve Orta Asya Müslümanları arasında büyük bir etki yaratmış, bu heyecandan istifade etmek maksadıyla Almanların da teşvikiyle Binbaşı Hüseyin Rauf Bey'in başkanlığında bir Türk-Alman Heyeti oluşturulmuştur. ${ }^{11}$ Mustafa Balcığlu ve İsrafil Kurtcephe ise Alman Genelkurmayı'nca planlanıp, Enver Paşa tarafından teşkil edildiğini iddia ettikleri heyetin kuruluş amacının; İran, Afganistan ve Hindistan'da İngiltere aleyhine ayaklanmalar çıkarmak olduğu kanısındadır. ${ }^{12}$ Vahdet Keleşyılmaz’a göre Teşkilât-1 Mahsusa’nın Şark Şubesi’nde görevli (Ömer) Fevzi Bey tarafından organize edilen bu heyetten beklenilen İran üzerinden Afganistan’a ulaşarak bu ülkeyi Cihad-ı Ekber’e kazandırmak suretiyle Hindistan sınırında mühim bir müttefik temin etmek ve bağımsızlık yanlısı Hint komitelerini destekleyerek İngilizlere karşı bir ayaklanma çıkarılmasını sağlamaktır. ${ }^{13}$ Bahse konu müfrezenin Teşkilât-ı Mahsusa ile ilintili olduğu yönündeki bir başka açılama da Mehmet Kenan Bey'den gelmiştir. Mehmet Kenan Bey; "Harbiye Nezareti şark şube-i mahsusasına memur Binbaşı Fevzi Bey tarafindan

9- İmparatorluk Döneminde Türk-Alman İlişkileri: Goltz Paşa'nın Hatıratı, Haz: Faruk Yılmaz, Poyraz Ofset, Ankara, 2004, s. 117-118.

10- Vahdet Keleşyılmaz, Teşkilât-ı Mahsusa'nın Hindistan Misyonu (1914-1918), Atatürk Araştırma Merkezi Yayınları, Ankara, 1999, s. 5. Bahse konu müfreze uluslararası literatürde ise genellikle Niedermayer Sefer Kuvveti veya Niedermayer-Hentig Heyeti olarak adlandırılmaktadır. Detaylı bilgi için bk. Ludwig W.Adamec, Afghanistan (1900-1923): A Diplomatic History, University of California Press, Los Angeles, 1967, p. 83-84.

11- Mehmet Saray, Afganistan ve Türkler, ASAM, Ankara, 2002, s. 103-110.

12- İsrafil Kurtcephe - Mustafa Balcığlu, "Birinci Dünya Savaşı Başlarında Romantik Bir Türk-Alman Projesi-Rauf Bey Müfrezesi”, Osmanlı Tarihi Araştırma ve Uygulama Merkezi (OTAM) Dergisi, Sayı: 3 (1992), s. 249 .

13- Vahdet Keleşyılmaz, a.g.e., s. 88-90. 
(semt-i meçhul) markasıyla hususi bir teşkilat yapılmıştır. Gayet mahrem tutulan bu teşkilat Binbaşı Hüseyin Rauf Kuvve-i Seferiyesi idi. Bu hey'et-i seferiye askeri olmaktan ziyade siyasi ve ihtilal hey'eti mahiyetinde Cenubi İan'dan Afganistan'a gidecek ve Afganistan'ı cihad-ı ekbere dâhil edecekti." ${ }^{4}$ demektedir. Dünya Casusluk Tarihi adlı eserde ise Hüseyin Rauf Müfrezesi'nin yaratıcısı olarak Enver Paşa gösterilmekte ve cihadı bütün İslam dünyasına yaymak gayesiyle, Bağdat'tan başlayarak İran’ın ortasından geçen ve Afganistan üzerinden Hindistan’a kadar uzanan bir yol açılmasının amaçlandığ 1 söylenmektedir. Ortadoğu ve Afganistan üzerine yaptığı çalışmalarla tanınan Avusturyalı akademisyen Ludwig W.Adamec de Afganistan’a bir heyet gönderme fikrini Enver Paşa'nın teklif ettiğini, Max von Oppenheim ve Sven Hedin gibi oryantalistlerin onayından sonra da bir müfrezenin oluşturulduğunu ifade etmektedir. ${ }^{15}$ Kadir Kon ise projenin arkasındaki isim olarak Max von Oppenheim’ı görmektedir. Kon’a göre Almanya’nın I. Dünya Harbi için öngördüğü ayaklanmalar suretiyle İngiltere, Fransa ve Rusyảnın zayıf düşürülmesi yönündeki politikasının İslam dünyası bölümü von Oppenheim’n elinden çıkmıştır ve bu fikir onda ilk kez 1898 yılında hazırladığı memorandum esnasında belirmiştir. Von Oppenheim 1914 yılında hazırladığı ve muhtemelen hazırlık safhasında Enver Paşa ile koordine ettiği ikinci memorandumda ise Müslüman nüfusun yoğun olarak yaşadığı Mısır-Rusya ve Hindistan topraklarında ihtilal çıkarma yolları ile propaganda/karşı propaganda usullerini detaylı olarak irdelemiştir. Memoranduma göre Hindistan’a yönelik bir harekâttan beklenti, İngiliz donanmasının kayda değer bir bölümünün buraya kaydırılarak Alman ordusunun işinin kolaylaştırılması ve Hindistan'da yaşayan çok sayıda İngiliz nüfus ve İngiliz yatırımını korumak için İngiltere’nin barış yapmaya zorlanmasıdır. ${ }^{16}$

Olayların merkezinde bulunan Hüseyin Rauf (Orbay) Bey ise hatıratında, Afganistan'ı Hindistan'daki İngilizlere karşı silahlandırıp tahrik etme fikrinin Alman İmparatoru'na ait olduğunu ifade etmektedir. ${ }^{17}$

14- Mehmet Kenan, Büyük Harpte İran Cephesi, (Osmanlıca Metin), Cilt: 2, Büyük Erkân-1 Harbiye Reisliği Ankara Matbaas1, Ankara, 1928, s. 140.

15- Ludwig W.Adamec, op.cit., p. 83-84.

16- Kadir Kon, “Almanya’nın İslam Stratejisi Mimarlarından Max von Oppenheim ve Bu Konudaki Üç Memorandumu”, Tarih Dergisi, Sayı: 53 (2012), s. 217-240. 18 Ağustos 1914 tarihinde Şansölye için hazırladığı raporda, bir taraftan İngilizlerin kara propagandasını çürütecek (karşı propaganda), bir taraftan da Almanya lehine propaganda yapacak bir birime ihtiyaç olduğunu söyleyen kişi de yine von Oppenheim'dır. Bu raporun ardından von Oppenheim başkanlığında 1 Kasım 1914 tarihinde kurulan “Doğu İstihbarat Birimi” "nin faaliyet sahalarından biri de İtilaf Devletleri kolonilerinde, tarafsız ülkelerde ve Almanlar tarafından esir alınan askerler üzerinde propaganda yaparak, bu hedef kitlenin Almanya ve/veya müttefiği Osmanlı Devleti saflarında savaşmalarını sağlamaktır. Detaylı bilgi için bk. Fatih Çolak, Alman Arşiv Belgelerine Göre Almanya 'nın Türkistan Siyaseti (1910-1920 Yılları Arasında), Yayımlanmış Doktora Tezi, Necmettin Erbakan Üniversitesi, 2019, s. 78-79. Esirlerin askeri amaçlarla kullanılmasında Almanya'nın İstanbul elçisi Wangenheim üzerinde etkili olan isim ise özellikle Enver ve Talat Paşa ile iyi ilişkiler içinde bulunan ve Osmanlı ordusunda çeşitli görevlerde bulunan Emir Şekip Arslan'dır. Şekip Arslan, harp başladığında Fransız ordusunda yer alan, ancak Almanlara esir düşen Kuzey Afrikal1 1.500 Müslüman esirin İstanbul'a gönderilmesinin ve Kuzey Afrika'da meydana gelebilecek bir ayaklanmaya Almanya'nın silah sağlamasının bütün İslam dünyasında büyük bir propaganda rüzgarı estireceği kanaatindedir. Detaylı bilgi için bk. Emir Şekip Arslan, Bir Arap Aydınının Gözüyle Osmanlı Tarihi ve 1. Dünya Savaşı Anıları, Çev: Selda Meydan, Ahmet Meydan, Çatı Kitapları, İstanbul, 2005, s. 328.

17- Rauf Orbay, Cehennem Değirmeni: Siyasi Hatıralarım, Emre Yayınları, İstanbul, 1993, s. 17-18. 
Ulusal ve uluslararası literatürde kabul gören bu yaklaşımlardan da istifade edilerek, Binbaşı Hüseyin Rauf Müfrezesi’nin kuruluş fikrinin Almanlara ait olduğu ve Enver Paşa’nın emelleri ile örtüşen bu yaklaşımın Türk cenâhında kabul görmesiyle harekete geçildiği yorumunda bulunulabilir. Cihad ilanından yaklaşık iki ay önce yola çıkacak olan bahse konu müfrezenin temel motivasyon kaynağı ise "Panislamizm (İttihad-ı İslam)"dir.

19'uncu yüzyılın ikinci yarısından itibaren "Yeni Osmanlılar" olarak adlandırılan bir grup genç tarafından gündeme getirilen Panislamizm II. Abdülhamit Dönemi’nde başarıyla uygulanmıştır. I. Dünya Harbi’nin başında, içinde bulunulan şartların da dayatmasıyla Osmanlı Devleti yine Panislamizm silahına sarılmış ve emperyalist güçlerin egemenlikleri altındaki sayısı milyonlarla ifade edilen Müslüman nüfusu harekete geçirmenin yollarını aramıştır. ${ }^{18}$ İngiltere boyunduruğu altında bulunan Hindistan ve Mısır ile Rus egemenliği altındaki Kafkasya’nın ayaklandırılmasını kendilerine öncelikli hedef olarak belirleyen ${ }^{19}$ Almanlar da Panislamizm'e büyük önem atfetmiş ve harbin seyrini etkileyebilecek önemli bir etken olarak görmüşlerdir. ${ }^{20}$

Harbin hemen başında Hindistan’a yönelik özel bir müfreze kurulmasının sebebini ise barındırdığı Müslüman nüfusun çokluğu ve İngiliz ekonomisi açısından taşıdığı değer açısından olduğu kadar, Ortadoğu coğrafyasına yönelik askeri faaliyetlerin buradaki ordu karargâhı üzerinden yönetiliyor olmasında aramak gerekir. Nitekim daha Ekim-1914'de Basra Körfezi'nde şaşırtma harekâtı yapmak, petrol tesislerini korumak/İngiltere’nin çıkarları doğrultusunda kullanabilmek için Abadan Adası'nı işgal etmek ve Basra Limanı'nı ele geçirmek için görevlendirilen İngiliz askeri birliklerinin hareket noktası Bombay olmuştur. ${ }^{21}$

İngiliz istihbarat raporlarına göre bu dönemde, gerçekten de Hindistan'da ayaklanma çıkarılmaya müsait bir ortam vardır ve Berlin'de Hindistan İhtilalci Komitesi adıyla yapılanan Hint-Alman ortak kuruluşunun organize ettiği Hindu, Müslüman ve Sih muhalifler ayaklanma için 21 Şubat (1915) tarihini belirlemişlerdir. ${ }^{22}$

18- Kadir Kon, Birinci Dünya Savaşı’nda Almanya'daki Müslüman Esir Kampları (1914-1918), Yayımlanmamış Yüksek Lisans Tezi, Marmara Üniversitesi, 2011, s. 9-13.

19- Selami Kılıç, "Birinci Dünya Savaşına Uzanan Süreçte Türk-Alman Yakınlaşması”, 1914'den 2014'e 100 'üncü Yılında Birinci Dünya Savaşı’nı Anlamak, Harp Akademileri Basımevi, İstanbul, 2014, s. 123-124.

20- Sean McMeekin, Berlin-Bağdat Demiryolu: Almanya'nın Doğu Hakimiyeti Mücadelesi ve Osmanlı Imparatorluğu (1898-1918), Çev: Azize F.Çakır, Picus Yayıncılık, İstanbul, 2012, s. 115.

21- Charles V.F.Townshend, Mezopotamya Seferim: Kurna, Kûtülamare ve Selmanıpâk Muharebeleri, Çev: Gürol Koca, Türkiye İş Bankası Kültür Yayınları, İstanbul, 2012, s. 37-38.

22- Plana göre o gün, Hindistan ordusunda görevli yerli birlikler cephanelikleri basacak, ihtilalcilere silah dağıtacak, İngiliz subayları öldürülecek ve Delhi’ye yürüyerek Hindistan'da cumhuriyet ilan edeceklerdir. Ancak İngiliz istihbaratının çalışmalarıyla bu plan deşifre edilmiş ve ihtilalcilerin bir kısmı bombalar,silahlar, broşür ve bayraklarla yakalanmışlardır. Ancak Hindistan'ın başka yerlerinde, özellikle de Bengal'de hala Almanya tarafından Amerika Birleşik Devletleri üzerinden tedarik edilecek silahları kabul etmeye hazır ihtilalci gruplar vardır ve bahse konu silahlar İngiliz yetki alanı dışında teslim edilecek şekilde planlama yapılmaktadır. Ayrıca Tayland-Burma sınırında, muhalif grupların Almanlar tarafından eğitilecekleri ve silahların depolanabileceği bir merkez de kurulmuştur. Detaylı bilgi için bk. Peter Hopkirk, İstanbul'un Doğusunda Bitmeyen Oyun, Çev: Mehmet Harmancı, Sabah Kitapları, İstanbul, 1995, s. 53-55. 
O tarihte Hindistan'a ulaşmak için Hilafet merkezi olarak görülen İstanbul'dan yola çıkacak bir misyonun Irak üzerinden İran’a geçmesi, İran'dan sonra da kuzeyden Afganistan veya güneyden Belucistan tarikiyle Hindistan’a ulaşması gerekmektedir. Bu durum, güzergahta bulunan ülkelerin de Türk-Alman ittifakı saflarına çekilmesi, şayet bu yapılamıyorsa en azından tarafsız kalmalarının sağlamasını zorunlu kılmaktadır.

$\mathrm{Bu}$ durumun farkında olan Almanlar, İran'ı İttifak Devletlerine katılmaya ikna edilebilirlerse, Alman askeri malzeme, para ve askeri personeliyle desteklenecek İran ordusunun Rus ve İngilizleri ülkeden kovacağ $1,{ }^{23}$ bu sayede yeni bir müttefik ve yeni bir nüfuz alanı elde edecekleri kanaatini taşımaktadır. Alman stratejistlerin üzerinde yoğunlaştığı bir diğer ülke de Afganistan'dır. Von Oppenheim’a göre o tarihte 40-50 bin askere sahip olan Afgan Emiri Habibullah Han'ın, Türk ve Almanların desteğiyle Müslüman bir ordunun başı olarak İngiltere yönetimindeki Hindistan'a saldırması bölgede bir domino etkisi yaratacak, Kahire'den Kalküta'ya kadar tüm dünya Müslümanları İngiltere’ye karşı ayaklanacak ve İngiltere’yi Almanya’nın menfaatine olacak bir barış anlaşması imzalamaya mecbur bırakacaktır. ${ }^{24}$ Alman Kayzeri Wilhelm ise İngiliz egemenliği altındaki milyonlarca Müslümanın ayaklandırılmasının önemini kavramakla birlikte, dinen Müslümanları cihada çağırma yetkisine sahip olmadığının ve bunun için altın, silah, savaş sonrasına dair vaatlerden çok daha fazlasının gerektiğinin farkındadır. Bu durum İslam dünyasının halifesi sıfatını taşıyan Osmanlı Sultanı’nın olaya müdahalesini zorunlu kılmaktadır. Konuyu daha da grift bir hale getiren bir başka husus da modern harplerde bir cihad örneği olmadığından, böylesine cüretkar bir teşebbüsün neticelerinin kestirilememesidir. ${ }^{25}$

İşte bu şartlar altında teşkiline başlanan müfrezenin komutanlığına Hüseyin Rauf Bey’in seçilmesinde Teşkilât-ı Mahsusa’nın öncülü olarak değerlendirilebilecek olan Özel Şube’nin sorumlusu Ömer Fevzi Bey etkili olmuştur. Heyete kurmay başkanı sıfatıyla katılan Ömer Fevzi Bey bu örtülü faaliyette daha evvelden tanıdığı bir şahsiyet olan Hüseyin Rauf Bey ile birlikte çalışmak istemiştir. Heyetin Alman bölümü ise istihbaratçı Willhem Wassmuss başkanlığında, güvenlikten sorumlu Yüzbaşı Oscar von Niedermayer’le birlikte gayrinizami harp alanında uzman on beş kişilik bir ekipten oluşmaktadır. Gizliliğin hat safhada tutulmaya çalışıldığıbu ekip için "semt-i meçhul" silah-teçhizat tedarik edilmiş ve "müstear isimler" belirlenmiştir. ${ }^{26}$

23- Joseph Pomiankowiski, Osmanlı Imparatorluğu’nun Çöküşü: 1914-1918 I. Dünya Savaşı, Çev: Kemal Turan, Kayıhan Yayınları, İstanbul, 1990, s. 134.

24- Sean McMeekin, a.g.e., s. 120-121, 260-261.

25- Peter Hopkirk, a.g.e., s. 1-4.

26- Mim Kemal Öke, Ömer Fevzi Mardin: Gazi ve Sufi, İrfan Yayımcılık, İstanbul, 2009, s. 58-60. Esasen Niedermayer ve adamları müfrezeye sonradan katılmışlardır. İlk kafilede Almanlar adına öne çıkan isim Wassmuss'dur. Ancak ilerleyen günlerde Wassmuss ile Niedermayer arasında çıkan anlaşmazlık nedeniyle Wassmuss heyetten ayrılacaktır. Bir başka dikkat çeken husus da müfrezedeki Alman personel sayısının burada on beş kişi olarak verilmesine karşın, farklı kaynaklarda otuz kişi olarak geçmesidir. Bu farkın, müfrezenin birkaç kafile halinde ve farklı zamanlarda hareket etmesinden kaynaklandığg değerlendirilmektedir. 
Heyetin hazırlıklarının devam ettiği sırada, Hindistan'da daha evvelden belirlenmiş olan yerel personelle irtibata geçerek, arkadan karayoluyla gelecek olan Binbaşı Hüseyin Rauf Müfrezesi için "harekât ortamını şekillendirmekle görevli” Yüzbaşı Murat ve Mülazım Nurettin Bey tüccar kiyafeti ve müstear isimlerle Hidiviye Vapuru'nu kullanarak İstanbul'dan Hindistan'a hareket etmişlerse de İngilizler tarafından yakalanmışlar ve operasyonun deşifre olmasına neden olmuşlardır. ${ }^{27}$

Bu esnada ilk iki kafilede personel, üçüncü kafilede ise malzemeler ve bu malzemelerden sorumlu personel olacak şekilde üç kafile halinde tanzim edilmiş olan müfrezenin Binbaşı Hüseyin Rauf, Binbaşı Ömer Fevzi, von Wassmuss ve yaverlerden oluşan ilk kafilesi 15 Eylül 1914 tarihinde İstanbul'dan trenle hareket etmiş ve dört gün sonra Halep'e, 13 Kasım'da ise Bağdat'a ulaşmıştır. ${ }^{28}$ Ancak burada Türk ve Alman heyetleri arasında çıkan anlaşmazlık nedeniyle heyetler müstakil hareket etmeye başlamıştır. ${ }^{29} \mathrm{Bu}$ ayrışmanın temel nedeni ise müfrezenin mali sorumluluğunun Almanlar tarafından yüklenilmesinin yarattığı havanın da etkisiyle Niedermayer' in komutayı devralmak istemesidir. ${ }^{30}$

Müfrezenin Türk ve Alman mensupları arasında yaşanan anlaşmazlık ve değișen konjonktür nedeniyle Osmanlı Devleti açısından Güney İran’ın kontrol altına alınmasının öncelik kazanmasıyla birlikte Afganistan üzerinden Hindistan’a yönelik olarak icra edilmesi planlanan harekâta ara verilmiş, ancak tamamen vazgeçilmemiştir. ${ }^{31}$ Başkomutanlık'tan

27- Vahdet Keleşyılmaz, a.g.e., s. 91.

28- Ahmet Tetik, Teşkilat-ı Mahsusa (Umûr-ı Şarkıyye Dairesi) Tarihi (1914-1916), Cilt: I, Türkiye İş Bankası Kültür Yayınları, İstanbul, 2014, s. 225-227.

29- Geçmişten Günümüze Türk-Afgan Illişkileri, Genelkurmay Başkanlığı ATASE Yayınları, Ankara, 2009, s. 33-35.

30- Ludwig W.Adamec, op.cit., p. 84. Hüseyin Rauf Bey, itaat etmek istemeyerek, kumandayı ele almak isteyen kişinin Alman murahhası Fon von Muss (Wassmuss) olduğu görüşündedir. Detaylı bilgi için bk. Rauf Orbay, a.g.e., s. 20.

31- 6'ncı ve 1'inci Ordu Komutanlığı görevlerinde de bulunmuş olan General Ali İhsan Sâbis, müfrezenin Hindistan'a yönelik faaliyetlerinin durdurulmasında Hüseyin Rauf Bey’in İran hududunu geçtikten sonra Kirina Boğazı'nda İranlı aşiretler tarafından silahlı mukabele görmesinin de etkili olduğu kanaatindedir. Sâbis'e göre, bu ilk teşebbüsün başarısız olması nedeniyle Kâzım (Karabekir) kumandasında daha büyük bir kuvve-i seferiye hazırlığı içine girilmişse de Kafkas Cephesi'ndeki gelişmeler nedeniyle bu düşünce hayata geçirilememiştir. Detaylı bilgi için bk. Ali İhsan Sâbis, Harp Hatıralarım: Birinci Dünya Harbi, Cilt: II, Nehir Yayınları, İstanbul, 1990, s. 258-259. Ali İhsan Sâbis'in bahsettiği ikinci (ve hatta üçüncü) müfrezeye dair detayları Kûtü’1 Amare Kahramanı olarak bilinen Halil (Kut) Bey'in anılarında bulmak mümkündür. Halil Bey'in anılarından; Birinci Cihan Harbi’nin başlamasıyla birlikte Enver Paşa'nın emriyle "Halil Bey Kuvve-i Seferiyesi" adı altında mürettep bir firka teşkil edildiği anlaşılmaktadır. Görevi Tebriz üzerinden Dağıstan'a yürüyerek, umumi bir isyan başlatmak ve Rusları Hazar Denizi kıyılarından tard etmek olan mürettep firkanın en son kademesi 19 Aralık 1914 tarihinde İstanbul'dan ayrılacak şekilde kademeli bir hareket planı hazırlanmıştır. Fırkasını daha evvelden planladığı üzere Urfa'da toplayan Halil Bey, burada bulunduğu sırada Başkumandanlık’tan gelen bir telgraf nedeniyle Enver Paşa ile görüşmek üzere Ulukışla'ya geçmiş ve o görüşmede, Kuvve-i Seferiye'nin Sarıkamış’ta alınan yenilgi nedeniyle zayıf düşen III. Ordu emrine verilmesi, Halil Bey için yeni bir kuvve-i seferiye teşkil edilmesi kararlaştırılmıştır. Gerçekten de bir süre sonra İstanbul'da "Birinci Halil Bey Kuvve-i Seferiyesi" teşkil edilmiş, ilk kuvve-i seferiye ile benzer bir güzergâhı takip eden bu birlik, İran sınırına ulaşmış ve Rus ordusuyla muharebeye girmiştir. Ancak Van'ın düşmesi, Bitlis ve Irak istikametinin tehlikeye girmesi nedeniyle Başkumandanlık Vekaleti’nin emriyle Halil Bey komutasındaki kuvve-i seferiye III. Ordu'nun emrine 
14 Aralık 1915’te verilen emir doğrultusunda Binbaşı Hüseyin Rauf’a tevdi edilen yeni görev Loristan’a hareket etmesi, bu bölgede yaşayan Bahtiyârîler ile iyi ilişkiler kurması ve yerel halktan teşkil edilecekbirliklerle Basra’da konuşlu İngiliz güçlerine karşı ayaklanma çıkarılmasıdır. ${ }^{32}$

Hüseyin Rauf Bey'in yeni görev bölgesi olan İran'da bu tarihte siyasi, idari ve askeri bakımdan tam bir karmaşa hâkimdir.

$\mathrm{Bu}$ karmaşanın en önemli sebeplerinden biri Rusya ve İngiltere arasında imzalanan 1907 tarihli antlaşma (Grey-Izwolsky Antlaşması) ile İran’ın nüfuz bölgelerine ayrılmış olmasıdır. ${ }^{33}$ İran’ın müdahil olamadığı anlaşmaya göre; ülkenin petrol kaynaklarının yoğunlaştığı bölgeler Rusya ve İngiltere arasında paylaşılarak, kuzey İran Rusya ve güney İran İngiltere’ye bırakılırken, orta kesim tarafsız kabul edilmiştir. ${ }^{34}$

$\mathrm{Bu}$ tarihten itibaren İran’a yönelik yalnızca ekonomik ve siyasi faaliyetlerin değil, istihbarat ve beşinci kol faaliyetlerinin de bariz bir şekilde arttığı görülmektedir. Tarafsızmış gibi görünen ve İran’ın bağımsızlığının savunucusu rolüne bürünen Almanya, bir yandan Kirmanşah'ta bulunan Nizamü'l-Saltana Hükümeti'ni resmen tanıyı, maddi olarak desteklerken, diğer taraftan da İran halkını İngiliz ve Ruslara karşı gerilla harbi vermeleri için teşvik etmektedir. ${ }^{35}$ Yine Almanya, cihat ilanına dayanarak, İran’ı -Şii olmasına rağmen- Osmanlı Devleti tarafında savaşa sokmaya çalışarak, hem Osmanlı’nın Kafkasya'daki yükünü hafifletecek, hem de Afganistan ve Hindistan Müslümanlarının ayaklanmalarına İran’ın da yardımcı olmasını sağlayacak politikalar üretmeye çalışmıştır. ${ }^{36}$

verılmış ve Halıl Bey gerı çekılmek zorunda kalmıştır. Detaylı bılgı 1çın bk. Halit Paşa: Tttihat ve Terakki 'den Cumhuriyet'e Bitmeyen Savaş-Kütûlamare Kahramanı Halil Paşa'nın Anıları, Haz: M.Taylan Sorgun, Yaylacık Matbaası, İstanbul, 1972, s. 136-139. Halil (Kut) Bey’in hayatını konu alan bir başka çalışmada da her iki kuvve-i seferiyenin teşkiline yönelik benzer ifadelere rastlamak mümkündür. Bahse konu eserde, Halil Bey'in anılarında "Halil Bey Kuvve-i Seferiyesi” olarak nitelediği Beşinci Kuvve-i Seferiye’nin görevine bir parça daha açıklık getirilmiş ve bu birliğin vazifesi, III. Ordu Kafkasya'daki Rus ordusu ile mücadele ederken, İran üzerinden başlatılacak bir harekâtla Rus ordusunu sıkıştırmak ve oradan da Türkistan, Afganistan ve Hindistan'a kadar yayılarak İngiltere ve Rusya aleyhinde faaliyetlerde bulunmak olarak gösterilmiştir. Eserde Beşinci Kuvve-i Seferiye'nin Halil (Kut) Bey idaresinde kurulduğu, sonraki günlerde de Kâzım (Karabekir) Bey liderliğinde, vazifesi Bağdat üzerinden İran'a yürüyerek, bu bölgeyi Ruslar'dan temizlemek ve işgal etme olan Birinci Kuvve-i Seferiye'nin kurulmasının planlandığı ifade edilmiştir. Görev emrinde açıkça belirildiği üzere komutanlarına geniş yetkiler tanınan her iki kuvve-i seferiyenin vazifesi de gayrinizami harp faaliyetlerinde bulunmaktır. Detaylı bilgi için bk. Mehmet Emin Dinç, Kûtü'lAmare’nin Muzaffer Komutanı Halil Kut Paşa, Kronik Kitap, İstanbul, 2017, s. 54-59.

32- İsrafil Kurtcephe - Mustafa Balcığlu, a.g.m., s. 259.

33- BOA, HR.SYS., D: 2340, G: 41-001-003, Tarih: 20.07.1917.

34- Ervand Abrahamian, "Factionalism in İran: Political Groups in the 14th Parliament (1944-1946)", Middle Eastren Studies, Vol: 14, No: 1 (1978) , p. 24-25.; Süleyman Erkan, “İran'a Yabancı Ülke Müdahaleleri (1907-1921)”, Akademik ORTA DOĞU Dergisi, Cilt: 5, Sayı: 1 (2010), s. 99.

35- Mustafa Şehitoğlu-Rahmi Doğanay, “İran Kaynaklarına Göre Nazi Döneminde Almanların İran'daki Casusluk ve Propaganda Faaliyetleri”, Furat Üniversitesi Sosyal Bilimler Dergisi, Cilt: 29, Sayı: 1 (2019), s. $450-451$. 36- Mustafa Çolak, Alman İmparatorluğu'nun Doğu Siyaseti Çerçevesinde Kafkasya Politikası (1914-1918), Türk Tarih Kurumu Yayınları, Ankara, 2006, s. 39-40. 
Bu dönemde İran’ın orta ve güney bölgelerinde faaliyet gösteren ve tarafsız gibi görünen İsveçli subayların kontrolündeki yasa ve düzeni korumakla görevli 6 bin kişilik jandarma kuvveti de Almanlara belirgin bir şekilde destek vermektedir. ${ }^{37}$ İngiltere ise hem İsveçli jandarma subaylarının, hem de müttefiklik ilişkisi içinde oldukları Rusya’nın faaliyetlerini yakından takip etmekte ve önlemler almaya çalışmaktadır. ${ }^{38}$ Ayrıca İngilizler İran'daki aşiretleri kendi çıkarları doğrultusunda kullanabilmek adına yoğun çaba harcarken, Ruslar da Hamedan yoluyla Kirmanşah’ı işgale hazırlanmaktadır. ${ }^{39}$ Osmanlı Devleti ise özellikle İttihat ve Terakki Cemiyeti ileri gelenlerinin çabalarıyla İran ile iyi ilişkiler kurma gayreti içindedir. ${ }^{40} \mathrm{Bu}$ dönemde Tahran'da bulunan Osmanlı Sefareti'nin çalışmaları son derece dikkat çekicidir. Sefaret yalnızca İran'da değil; Irak, Rusya, Afganistan ve Hindistan'a kadar uzanan geniş bir bölgede yoğun bir faaliyet içindedir. İran'da Rus ve İngiliz nüfuzunu kırmak adına Osmanlı Devleti’nin Teşkilât-ı Mahsusa aracılığıyla yaptığı operasyonların organize edilmesi, Rusya ve Türkistan'dan gelen istihbarat raporlarının merkeze ulaştırılması, Almanların zararlı faaliyetleriyle mücadele edilmesi, Osmanlı Devleti-Almanya ve İran arasında bir ittifak antlaşması sağlanması ${ }^{41}$ bölgenin geleceğine dair stratejiler üretilmesi ve Afganistan’a yönelik faaliyetler için ihtiyaç duyulacak altyapının hazırlanması Sefaret’in iştigal ettiği faaliyetlerden ön plana çıkanlardır. ${ }^{42}$

Afganistan’a gitmek amacıyla yola çıkan, ancak İran'da takılıp kalan ve Enver Paşa’nın emriyle "Cenubî İran Başkumandanlı̆̆ı" sıfatıyla bu bölgede faaliyet göstermeye başlayan, çalışmaları esnasında zaman zaman Tahran Sefareti, Irak ve Havalisi Kumandanlığı ve Teşkilât-1 Mahsusa ile çekişmeler yaşayan Binbaşı Hüseyin Rauf Müfrezesi'nin faaliyetlerine dair çok sayıda arşiv belgesi bulunmaktadır. Bu belgeler, bahse konu coğrafyaya atfedilen önemi, müfrezenin misyonunu ve o dönemde yaşanan sıkıntıları göz önüne sermesi açısından ehemmiyet arz etmektedir.

Bu belgelerden biri olan Hüseyin Rauf Bey'in Hanekin'den “Dersaadet Başkumandanlık Vekâlet-i Celilesi”ne hitaben gönderdiği 7 Nisan 1915 tarihli telgraftan; Irak ve İran coğrafyasında İngiliz ve Ruslar'ın Osmanlı Devleti aleyhine faaliyetlerde bulunduğu ve bir taburluk bir kuvvete sahip olan Hüseyin Rauf Bey’in, İran aşiretleriyle iyi ilişkiler kurduğu, onlarıOsmanlıDevleti’ne sadık kalmalarıiçin ikna ettiğianlaşılmaktadır. Telgrafta Teşkilât-1 Mahsusa ile Hüseyin Rauf Bey arasında bir çekişme yaşandığ 1 ve Hüseyin Rauf Bey’in, gayr-1 mesul olarak tanımladığı Teşkilât-1 Mahsusa mensuplarının kendi işlerine

37- Selami Kılıç, "Birinci Dünya Savaşına Uzanan Süreçte Türk-Alman Yakınlaşması”, 1914'den 2014'e 100 'üncü Yılında Birinci Dünya Savaşı'nı Anlamak, Harp Akademileri Basımevi, İstanbul, 2014, s. 127.

38- British Documents on Foreign Affairs: Reports and Papers from the Foreign Office Confidental Print, Series: B (Persia, Britain and Russia 1907-1914), Vol.: 14 (12 March 1914), University Publications of America, p. $420-421$.

39- BOA, HR.SYS., D. 2316, G: 14, Tarih: 25.10.1914.

40- M. Volkan Atuk, “İttihat ve Terakki Cemiyeti'nin İran Politikası”, Belleten, Cilt: 83, Say1: 296 (2019), s. 262.

41- Çağdaş Yüksel, “Birinci Dünya Savaşı’nda Ataşemiliter Ömer Fevzi Bey’in İran'daki Faaliyetleri”, Ulakbilge Sosyal Bilimler Dergisi, Cilt: VI, Sayı: 30 (2018), s. 1551.

42- BOA, HR.SYS., D: 2407, G: 31, Tarih: 16.03.1915. 
karışmasını istemediği de görülmektedir. ${ }^{43}$ Enver Paşa ise Hüseyin Rauf Bey'den Teşkilât-1 Mahsusa’nın etkin olduğu Irak'taki kuvvetlere yardım etmesini istemiş, ${ }^{44}$ kendisinin vazife-i asliyesinde müstakil olmasına rağmen; tekmil mıntıkanın müdafaa mesuliyetinin Teşkilât-ı Mahsusa'nın ilk başkanı olup, 20/21 Aralık 1914 tarihinde Irak ve Havalisi Kumandanlığı’na atanmış olan ${ }^{45}$ Süleyman Askeri Bey'de olduğu hatırlatılmıştır. ${ }^{46}$

Harbiye Nezareti’nden 11 Nisan 1915 tarihinde Hüseyin Rauf Bey’e çekilen başka bir telgrafta ise Emir Müftehem ile görüşülerek İran dâhilindeki efkârı Osmanlı lehine çevirmesi ve İranlılarla hüsn-ü münasebet te'sisine sarf-1 gayret edilmesi istenmiştir. ${ }^{47}$ Hüseyin Rauf Bey tarafından aynı gün Kasr-1 Şirin'den Harbiye Nezareti’ne çekilen şifreli telgrafta ise; "İraniler ile Sencabiler hariç olmak üzere bu havalideki aşâir ile i'tilâf edildiği marûzdur." ifadesine yer verilmiştir. ${ }^{48}$ Aynı tarihli başka bir telgrafta da "Emir Müftehem ordusu kumandan ve zabitanıla beraber hareket etmek üzere i'tilaf ve ittifak edildiği ve şu surette Emir Müftehem'in mütecavizâne mazarratına nihayet verileceği ma'ruzdur." denilmektedir. ${ }^{49}$ Hüseyin Rauf Bey'in 12 Nisan 1915 tarihli şifreli telgrafında, Emir Müftehem'in Sencabileri İngiliz himayesinde bulunmaları nedeniyle te'dip edemeyeceğini söylediği, Tahran Almanya Ataşemiliteri huzurunda resmen tasdik edildiği cihetle Kasr-1 Şirin'in ancak ve münhasıran İngiliz nüfuz ve himayesinde bir memleket telâkki edilebileceği bildirilmiştir. ${ }^{50} 15$ Nisan 1915 tarihli şifreli telgrafta iseçevredeki aşiretler ve Emir Müftehem kuvvetleriyle mutabakat sağlandığı, bunların cihad-ı mukaddese iştirak etme talebinde oldukları, teenni ile hareket edildiği ve zorunlu gereksinimler için talep edilen paranın henüz ellerine geçmediği bildirilmektedir. Bahse konu telgraftan, Sencabilerin İngilizlerle birlikte hareket için ittifak yaptıklarına dair istihbarat edinildiği

43- ATASE Arşivi, BDH Koleksiyonu, Klasör 7, Dosya 37A-004, Tarih: 08.03.1330-31.05.1331.

44- ATASE Arşivi, BDH Koleksiyonu, Klasör 7, Dosya 37A-005-1, Tarih: 08.03.1330-31.05.1331.

45- ATASE Arşivi, BDH Koleksiyonu, Klasör 3603, Dosya No: 3-2-8, Tarih: 1.12.30-23.12.30. K.K.K.lığı Emeklilik Şubesi Arşiv kayıtlarında Süleyman Askeri Bey’in bu göreve atanma tarihi 2 Ocak 1915 olarak geçmektedir. Detaylı bilgi için bk. Birinci Dünya Savaşı'na Katılan Alay ve Daha Üst Kademedeki Komutanların Biyografileri, Yay.Haz: Hülya Toker, Nurcan Aslan, Cilt: III, Genelkurmay Basımevi, Ankara, 2009, s. 264-265.

46- ATASE Arşivi, BDH Koleksiyonu, Klasör 7, Dosya 37A-007-01, Tarih: 08.03.1330-31.05.1331. Enver Paşa, aynı gün Irak Havalisi Kumandanlığı’na (Süleyman Askeri Bey’e) çektiği telgrafta da Hüseyin Rauf Bey ile yaşanan ihtilafın büyütülmemesini istemiştir. Detaylı bilgi için bk. ATASE Arşivi, BDH Koleksiyonu, Klasör 7, Dosya 37A-007-02, Tarih: 08.03.1330-31.05.1331. Süleyman Askeri Bey bu bölgeye Osmancık Gönüllü Taburu ile birlikte gelmiştir. Süleyman Askeri Bey genel idaresinde ve Tabur Kumandanı Yüzbaşı Cemil Bey’in komutasındaki bu tabur, Kafkasya'da özel harekât görevlerinde bulunmak üzere seçkin subaylar komutasında 100’er kișilik 6 bölük halinde örgütlenmiș bir yapıdır. Detaylı bilgi için bk. Birinci Dünya Harbinde Türk Harbi: Irak-Iran Cephesi (1914-1918), Cilt: III, 1’nci Kısım, Genelkurmay Basımevi, Ankara, 1979, s. 120. Irak Cephesi'nin sol kanat emrine verilen ve "müstakil bir fedai taburu” gibi görev yapan bahse konu tabur "yardımcı bir kuvvet olarak” düzenli orduya destek vermiş ve geceli-gündüzlü yapmış olduğu baskınlar ile İngiliz ordusunu taciz etmiştir. Detaylı bilgi için bk. Hamza Osman Erkan, Bir Avuç Kahraman, İnkılâp Kitabevi, İstanbul, 1946, s. 6-15.

47- ATASE Arşivi, BDH Koleksiyonu, Klasör 7, Dosya 37A-008-1, Tarih: 08.03.1330-31.05.1331.

48- ATASE Arşivi, BDH Koleksiyonu, Klasör 7, Dosya 37A-009, Tarih: 08.03.1330-31.05.1331.

49- ATASE Arşivi, BDH Koleksiyonu, Klasör 7, Dosya 37A-009-2, Tarih: 08.03.1330-31.05.1331.

50- ATASE Arşivi, BDH Koleksiyonu, Klasör 7, Dosya 37A-009-1, Tarih: 08.03.1330-31.05.1331. 
de anlaşılmaktadır. ${ }^{51}$ Başka bir şifreli telgrafta ise Hüseyin Rauf Bey'in maiyetinde, Kürt ve İranlı aşiretlerden 3 bin kişilik bir kuvvet toplandığ 1,800 kişilik ilave bir kuvvet için "icap edenlere" emir verilmesinin istendiği, ayrıca maddi sıkıntıların hat safhada olduğu ifade edilmiştir. İhtiyaç duyulan bütçenin tahsis edilmesi durumunda, Rus ve İngilizlere karşı daha önceden kararlaştırılan ayaklanmanın mümkün olacağına vurgu yapan bu telgraf İran'da İngiliz ve Ruslar ile onlara müzahir olan gruplara karşı uygulanan gayrinizami harbin en net ifadelerinden biridir. $^{52}$

20 Nisan 1915 tarihli bir telgraftan Enver Paşa’nın şifahi emri gereği Hüseyin Rauf Bey’e "örtülü ödenekten" 10 bin liranın tahsis edildiği anlaşılmaktadır. ${ }^{53} 21$ Nisan 1915 tarihli başka bir telgrafından ise geri kalan 10 bin liranın birkaç güne kadar gönderileceği ve Hüseyin Rauf Bey'in istediği ilave kuvvetlerin hazırlandığ 1 sonucu çıkarılabilir. ${ }^{54} \mathrm{Bu}$ esnada İran makamlarının müfrezenin faaliyetlerine kayıtsız kalmadığı ve rahatsızlık duydukları görülmektedir. Nitekim İran Sefareti’nden alınan 19 Nisan 1915 tarihli bir takrirde; asker ve aşiret mensuplarından oluşan 6 bin kişilik bir kuvvetin bir süredir Hüseyin Rauf Bey’in komutası altında İran'ın Kirmanşah hududunda kaîn Koreto ve Hanekin'de faaliyet gösterdiği bildirilmiş ve iki İslam devleti arasındaki münasebeti bozacak bu davranıştan vazgeçilmesi istenmiştir. ${ }^{55}$ Bahse konu takrir çok etki yaratmamış olacak ki Hüseyin Rauf Bey'in 25 Nisan 1915 tarihli telgrafında Hanekin'den Kirmanşah’a kadar olan bölgedeki aşiretlerin neredeyse tamamıyla İttihâd-ı İslam esası üzerine anlaşma akd edildiği ve İngilizlerle işbirliği yapmış olan Sencabilerin yola getirildiği bildirilmiş ve İran'da yürütülen gayrinizami harp faaliyetlerinin başarısına vurgu yapılmıştır. ${ }^{56}$

Bu dönemde İran Hükümeti’nden beklenen resmi olarak tarafsız görünmesi; gerçekte ise Türk tarafının faaliyetlerine gizlice destek vermesidir. ${ }^{57}$ Binbaşı Hüseyin Rauf tarafından Başkumandanlık Vekâleti’ne gönderilen 15 Mayıs 1915 tarihli telgrafta; Goran hâkimi Kirmanşah ve havalisi büyük reislerinden müşirpâyeli Serdar-1 Muazzam Hakin Han'ın Osmanlı tarafında yer aldığ 1 bildirilmiştir. ${ }^{58}$ Yine bu dönemde Binbaşı Hüseyin Rauf'un talebi doğrultusunda ${ }^{59}$ Kirmanşah ve havalisindeki İran kuvvetleri kumandanı ve müşir pâyeli Muhtarü’s-saltana albaylık rütbesi ile Ordu-yu Osmaniye'ye dahil edilmiş; ancak gerek İran hükümetinin ve gerekse kendisinin müşkül bir duruma düşmemesi için bu durum gizli tutulmuştur. ${ }^{60}$

Hüseyin Rauf Bey’in,İran’ın güneyinde faaliyetlerinde zorlandı̆̆ 1 dönemde Kaçar

51- ATASE Arşivi, BDH Koleksiyonu, Klasör 7, Dosya 37A-009-3, Tarih: 08.03.1330-31.05.1331.

52- ATASE Arşivi, BDH Koleksiyonu, Klasör 7, Dosya 37A-013 ve 013-1, Tarih: 08.03.1330-31.05.1331.

53- ATASE Arşivi, BDH Koleksiyonu, Klasör 7, Dosya 37A-013-3, Tarih: 08.03.1330-31.05.1331.

54- ATASE Arşivi, BDH Koleksiyonu, Klasör 7, Dosya 37A-013-5, Tarih: 08.03.1330-31.05.1331.

55- ATASE Arşivi, BDH Koleksiyonu, Klasör 7, Dosya 37A-017, Tarih: 08.03.1330-31.05.1331.

56- ATASE Arşivi, BDH Koleksiyonu, Klasör 7, Dosya 37A-017-5 ve 6, Tarih: 08.03.1330-31.05.1331.

57- ATASE Arşivi, BDH Koleksiyonu, Klasör 7, Dosya 37A-024-1, Tarih: 08.03.1330-31.05.1331.

58- ATASE Arşivi, BDH Koleksiyonu, Klasör 7, Dosya 37A-016-025, Tarih: 08.03.1330-31.05.1331.

59- ATASE Arşivi, BDH Koleksiyonu, Klasör 7, Dosya 37A-016-030, Tarih: 08.03.1330-31.05.1331.

60- ATASE Arşivi, BDH Koleksiyonu, Klasör 7, Dosya 37A-030-1, Tarih: 08.03.1330-31.05.1331. 
Hanedanı'ndan Mehmet Ali Şah’ın kardeşi olan Salarüddevle'den de istifade etmenin yollarını aradığı ve bu amaçla 29 Haziran 1915 tarihinde Enver Paşa’nın yardımına başvurduğu görülmektedir. Sonraki günlerde Almanlar tarafından silah ve mühimmatla teçhiz edilen bu şahsın İran'ı yabancı işgalinden kurtarmak için yola çıktığı haberi gazetelere yansımış ve Osmanlı Devleti kontrolündeki Salarüddevle İran’ın mevcut yönetimi ile Rus ve İngiliz işgal kuvvetlerine karşı bir tehdit unsuru olarak kullanılmıştır. ${ }^{61}$

Ancak tüm bu çabalara rağmen 15 Eylül 1915 tarihi itibariyle Binbaşı Hüseyin Rauf Müfrezesi artık işlevini kaybetmiş bir haldedir. Kirmanşah ve Hanekin bölgelerinde faaliyet gösterilmiş; ancak daha öteye geçilememiştir. Almanların olumsuz davranışları Osmanlı Devleti’nin amaçlarına ulaşmasını engellerken, düşmanları olan İngilizlerin daha da güçlenmelerine sebep olmuștur. Başkumandanlık Vekaleti de Hüseyin Rauf Bey’i Afganistan'a "askeri delege" olarak tayin ederken, emrindeki müfreze de Irak ve Havalisi Kumandanlığı'na bağlanmış ve İran topraklarından çıkmıştır. ${ }^{62} 15$ Eylül 1914'de binbaşı rütbesiyle Afganistan'a ulaşmak ümidiyle İstanbul'dan hareket eden Hüseyin Rauf Bey, bir yıl sonra yarbay rütbesiyle, Kerkük üzerinden İstanbul'a geri dönmüştür. ${ }^{63}$ Türklerle yaşadığ fikir ayrılığ sonrasında müstakil hareket eden Alman heyetinden Yüzbaşı Oscar von Niedermayer ve doktor von Hentig gibi isimler ise 1915 yll yazında (20/21 Ağustos 1915) Afganistan’a ulaşmış ve Habibullah Han ile görüşmüşse de, somut bir başarı elde edememişlerdir. ${ }^{64}$

\section{MÜFREZENIN FAALIYYTLERININ GAYRINIZIZAMI HARP AÇISINDAN DEĞERLENDİRILMESI}

Literatürde Binbaşı Hüseyin Rauf (Orbay) Müfrezesini tam bir ölçüsüzlük örneği olarak değerlendirerek, Osmanlı Devleti’nin bu teşebbüsleri başarıya ulaştıracak kadro ve gücü bulunmadığı, (İngiliz) Entelijans Servisi'ne karşı mücadele etmenin mümkün olmadığ $1{ }^{65}$ bu nedenle bahse konu teşebbüsten hiçbir netice alınamadığ ${ }^{66}$ ve İran içinde tutsak kalınarak, neticesiz çarpışmalar yaşandığ 1 yönünde iddialarla sıkça karşılaşılmaktadır. ${ }^{67}$

Esas itibariyle bu ifadelerde gerçeklik payı olmakla birlikte, modern gayrinizami harp teorisi açısından yapılacak bir değerlendirme neticesinde bahse konu müfrezenin kuruluş gayesi ve faaliyetlerine yeni anlamlar yüklenerek, bilinen/görünenden daha farklı

61- Sadık Sarısaman, “Birinci Dünya Savaşı'nda Salarüddevle Olayı”, Atatürk Üniversitesi Türkiyat Araştırmaları Enstitüsü Dergisi, Sayı: 2 (2010), s. 149-153.

62- Ahmet Tetik, a.g.e., s. 244-245.

63- Mim Kemal Öke,a.g.e., s. 65-66.

64- Geçmişten Günümüze Türk-Afgan ..., s. 33-35.

65- İsrafil Kurtcephe - Mustafa Balcıŏlu, a.g.m., s. 268-269.

66- Akdes Nimet Kurat, a.g.e., s. 500-501.

67- Barış Metin, Birinci Dünya Savaşı ’nda İran Coğrafyasında Etnik, Dini ve Siyasi Nüfuz Mücadeleleri, Yayımlanmış Doktora Tezi, Ankara Üniversitesi, 2007, s.48- 65. 
sonuçlara ulaşılabilir.

$\mathrm{Bu}$ bağlamda yapılması gereken ilk iş, bahse konu müfrezenin doğru adlandırılmasıdır. Çünkü literatürde sıklıkla kullanılan "Liasion Operations (Liyezon Operasyonları)" veya "Türk-Alman Ortak/Müssterek Harekâtı” şeklindeki tanımlamalar müfrezenin teşkil şekli ve misyonu açısından askeri terminolojiyle örtüşmemektedir. Liyezon operasyonları iki veya daha fazla ülkenin (istihbarat) servisleri arasında işbirliğinden başlayıp, ortak operasyonlara kadar uzanan faaliyetleri kapsamaktadır. ${ }^{68}$ Oysa bahse konu müfrezenin teşkil aşamasında Alman ve Türk istihbarat birimlerinin etkisi/katkısı bulunmakla birlikte, faaliyetlerin tamamı Almanların inisiyatifinde yürütülmemiştir. Türk tarafı açısından bakıldığında, müfreze mensuplarından bazılarının Teşkilât-ı Mahsusa bünyesinde görev almış olmaları dışında, bugüne kadar bahse konu müfrezenin Teşkilât-ı Mahsusa tarafından kurulduğuna dair hiçbir belgeye ulaşılmış değildir. Yine Hüseyin Rauf Bey’in Teşkilât-1 Mahsusa mensuplarıyla ters düştügü ve onları işine karıştırmadığı, emir ve talimatları Teşkilât-1 Mahsusa'dan değil; doğrudan doğruya Enver Paşa'dan aldığı ve kendisiyle sürekli muhabere ettiği konusunda da hiçbir tereddüt yoktur. Bu konuda vurgulanması gereken bir başka husus da Teşkilât-ı Mahsusa’nın yaygın kanının aksine yalnızca bir istihbarat teşkilatı değil; erken dönem bir gayrinizami harp örgütü olduğudur. ${ }^{69}$ Diğer taraftan bu müfrezeyi bir ortak/müşterek harekât birimi olarak adlandırmak da doğru değildir. Çünkü müşterek harekâtın birden fazla kuvvetin (kara-deniz-hava ve/veya özel kuvvetler) katılımıyla gerçekleştirilmesi gerekir. Bu sebeple, bahse konu müfrezenin üstlendiği görevi, iki veya daha fazla devletin iştirakiyle icra edilen bir "birleşik harekât" olarak kabul etmek $^{70}$ ve askeri terminolojiye uygun olarak "Türk-Alman Birleşik Harekâtı"şeklinde adlandırmak daha doğru bir yaklaşım olacaktır.

Bahse konu müfrezenin belirlenen hedeflere ulaşmak için konvansiyonel birliklerden farklı olarak "gayrinizami harp usullerini benimsediği" konusunda şüphe yoktur. Dönemin şahitlerinin de ifade ettiği üzere bir "ihtilal heyeti" mahiyeti taşıyan müfreze "semt- $i$ meçhul” silah-mühimmatla donatılmıştır. Bu tercihin, müfreze personelinin ve organize edeceği yerel güçlerin arkasındaki ülkenin tespit edilmesini önlemek amacına matuf olduğu söylenebilir. Yine müfreze için hazırlanan, ancak (bir süre) Romanya gümrüğünde alıkonulan sandıkların içindeki sabotaj malzemeleri, silah ve evraklar da müfrezenin üstlendiği misyona dair ipuçları vermektedir. ${ }^{71}$

Müfrezenin askeri terminolojiye uygun olarak adlandırılarak, misyonunun belirlenmesinden sonra yapılması gereken, bu konudaki çalışmalarda sıkça vurgulanan

68- Mehmet Eymür, Analiz: “Bir MİT Mensubunun Anılarl”, Elif Kitabevi, İstanbul, 2005, s. 212-213.

69- Zeynel Levent, Kuva-yı Milliye'den Teşkilât-ı Mahsusa'ya Gayrinizami Harp, Yayımlanmamış Doktora Tezi, Ankara Üniversitesi, 2019, s. 111; Polat Safi, The Ottoman Special Organization-Teşkilât-ı Mahsusa: An Inquiry into its Operational and Administrative Characteristics, Yayımlanmamış Doktora Tezi, İhsan Doğramacı Bilkent Üniversitesi, 2012.

70- Department of Defence (DoD) Joint Publication (JP) 1-02, Dictionary of Military and Associated Terms, Joint Chiefs of Staff, USA, 2001, p. 287, 293, 360.

71- Başlangıcından Bugüne Dünya Casusluk Tarihi, Cilt: I, Artel Yayınları, İstanbul, 1974, s. 196-197. 
"bu tür teşebbüsleri başarıya ulaştıracak kadro ve güce sahip olunmadiğı" yargısının doğruluğunun sınanmasıdır. Müfreze personelinin vasıfları açısından bakıldığında, Türk tarafında müfrezenin iki numaralı ismi olan Ömer Fevzi Bey’in, Alman tarafında ise Wassmuss ve Niedermayer gibi isimlerin gayrinizami harp ve gayrinizami harple yakın ilişki içindeki istihbarat konusunda yetkin isimler oldukları görülecektir. Müfreze komutanı pozisyonundaki Hüseyin Rauf Bey ise kruvazör harbinde son derece mahir bir bahriye subayı olmakla birlikte, gayrinizami harp konusunda bir altyapısının/tecrübesinin olmadığı bilinmektedir.

Bu durum müfrezenin planlama, teşkil ve görev bölgesine intikal sürecinde Ömer Fevzi Bey’i ön plana çıkarmaktadır. Kendisinin gayrinizami harp konusunda büyük bir tecrübeye sahip olduğu konusunda hiçbir tereddüt yoktur. Hüseyin Rauf Bey'in anlatımıyla Ömer Fevzi Bey Osmanlı-İtalyan Harbi’ne katılmış; Irak, Filistin ve Suriye'de teşkilat yapmış; Umumi Karargâh Şark Şubesi Müdürlüğü vazifesini üstlenmiştir. ${ }^{72}$ Kâzım Karabekir Paşa da Harbiye Nezareti Karargâhı’nda konuşlu olan “Şube-i Mahsusa (Özel Şube)”nın Ömer Fevzi Bey tarafından yönetildiğini ve Osmanlı Devleti’nin harbe girmesiyle birlikte bu şubenin "Teşkilât-ı Mahsusa"ya evrildiğini ifade etmektedir. ${ }^{73}$ Yine Harbiye Nazırı Enver Paşa adına Nisan 1914'de Katar'da örtülü faaliyetlerde bulunan Ömer Fevzi Bey'in, Osmanlı ordusu bu bölgeyi terk etmeden önce İngilizlere karşı koyabilecek bir milis kuvvetini organize etme yolunda girişimlerde bulunduğu da bilinmektedir. ${ }^{74}$ Müfrezede görevli diğer Türk personelin vasfı hakkında detaylı bilgi sahibi olunmamakla birlikte müfrezenin çoğunlukla yüzbaşı ve üsteğmen rütbesinde subaylardan oluşmasi ${ }^{75}$ noktasından hareketle, temel askeri harekât nevilerini bildikleri ve gerek İran'da, gerekse Afganistan/Hindistan coğrafyasında yerel halktan teşkil edilecek gerilla ve konvansiyonel ordu birliklerini yönlendirebilecek yeterlilikte oldukları çıkarımında bulunulabilir.

Müfrezenin Alman katılımcıları açısından bakıldı̆̆ında,alanlarının uzmanı olan Wassmuss ve Niedermayer dışındaki otuz kadar Alman personelin de asker-sivil ayrımı gözetmeksizin gayrinizami harp ve istihbarat alanında tecrübe sahibi oldukları söylenebilir. Ağırlıklı olarak askerlerden müteşekkil bu grup içinde (bir kısmı maske olarak kullanılan) çok farklı meslek gruplarından insanlar vardır. Belucistan, Afganistan ve Hindistan coğrafyasına hâkim olan zoolog Erich Zugmayer, Fransızca-İngilizce-RusçaYidiş-Moğolca ve Shavili dillerinde uzman olan Hermann Consten, Niedermayer'in doktor olan kardeşi Fritz ve yaveri Hans Jacob bunlardan ilk akla gelenlerdir. ${ }^{76}$

Müfrezenin faaliyetlerinin başarısı ise konvansiyonel birliklerin başarı kriterlerinden

72- Rauf Orbay, a.g.e., s. 18-19.

73- Erkân-1 Harbiye külliyatında eski Türkçe olarak bulunan bu eser Emrullah Tekin tarafindan transkribe edilerek "Gizli Harp: Istihbarat” adıyla 1998 yılında yeniden yayımlanmıştır. Detaylı bilgi için bk. Kâzım Karabekir, Gizli Harp: İstihbarat, Yay.Haz: Emrullah Tekin, Kamer Yayınları, İstanbul, 1998, s. 67.

74- Zekeriya Kurşun, Basra Körfezinde Osmanlı-İngiliz Çekişmesi: Katar'da Osmanlılar (1871-1916), Türk Tarih Kurumu Yayınları, Ankara, 2004, s. 150.

75- ATASE Arşivi, BDH Koleksiyonu, Klasör 3610, Dosya 30, Tarih: 00.07.1330-00.11.1331.

76- Sean McMeekin, a.g.e., s. 126-129, 269-284. 
farklı olarak, gayrinizami harp parametreleri ile ölçülebilir. Çünkü ilk teşkil sebebi olan Afganistan ve Hindistan’a ulaşılamamış olmakla birlikte, o tarihte esaslı ve devamlı bir askerlik usulüne sahip olmayan, ${ }^{77}$ önemli bir bölümü İngiliz-Rus işgali altında bulunan, merkeze uzak yerlerde ise aşiretlerin söz sahibi İran coğrafyasında gayrinizami harp açısından önemli faaliyetlerde bulunulmuştur.

Bu bağlamda vurgulanması gereken ilk husus, Hüseyin Rauf Bey'in İran'da yapmaya çalıştığı şeyin, modern gayrinizami harp teorisinde bugün “eğit-donat" olarak tanımlanan faaliyetin neredeyse bütün özelliklerini taşıyor olmasıdır. Kendisi 23 Haziran 1331 (1915) tarihinde İsmail Canbulat Bey’e gönderdiği mektupta, Irak’ın şark hududunu muhafazaya memur edilmiş vasıfsız 700 kadar adamın mahiyetine verildiğini, bunları İstanbul'dan getirttiği elbise ve silahlarla teçhize çalıştığını, bir fayda vermesi müşkil olan bu ehemmiyetsiz müfrezeyi kıymetli ve fedakâr subay arkadaşlarının çabalarıyla düzene soktuğunu ifade etmektedir. ${ }^{78}$

Hüseyin Rauf Bey’in bu dönemde ağırlıklı olarak yerel halktan kurduğu bu birliklerle Osmanlı Devleti karşıtı aşiretlerin tasallûtlarına nihayet vermek için gösterdiği gayreti ${ }^{79}$ de "gayrinizami kuvvetlere karşı harekât" kapsamında değerlendirmek mümkündür. ${ }^{80}$ Nitekim kendisi hatıratında, “Cenubi İran Başkumandanı" sıfatıyla İran'da ve Irak sınırında İngilizler ve onların desteklediği Sencabi aşiretine karşı mücadele ettiğini, burada tam bir yıl boyunca icra-yı hükümette bulunduğunu, bölge halkından vergi topladığını ve Bağdat'ı İngilizler’e karşı himaye ettiğini belirtmektedir. ${ }^{81}$

$\mathrm{Bu}$ dönemde Hüseyin Rauf Bey’in verdiği mücadelenin "hami ülke” sıfatıyla Osmanlı Devleti tarafindan Teşkilât-1 Mahsusa ve Tahran Sefareti üzerinden örtülü olarak desteklendiği görülmektedir.

Müfrezenin yola çıkmasından çok kısa bir zaman önce (29 Ağustos 1914) Erzurum'dan Bahaddin Şakir Bey tarafından Teşkilât-ı Mahsusa Merkez-i Umumisi aracılı̆̆ıyla, Enver Paşa'ya gönderilen bir raporda; İran’a yönelik çete teşkili yapılarak, Ömer Naci Bey riyasetinde yola çıkarıldığı bildirmekte, ${ }^{82}$ diğer yandan da Tahran Sefiri vasıtasıyla İran Hükümeti’ne haber gönderilerek, gelen müfreze için Kerbela'daki müçtehidler tarafından fetvalar neşredilmesini istenmektedir. ${ }^{83} \mathrm{Bu}$ tarihten yaklaşı dört ay sonra Ömer Naci Bey’in, Başkumandanlığa gönderdiği 2 Ocak 1915 tarihli telgraftan da Musul'dan sevk

77- Muhtasar İran ve Ordusu, Büyük Erkânıharbiye Matbaası, Ankara, 1930, s. 7.

78- Vahdet Keleşyılmaz, a.g.e., s. 91-92.

79- Ali İhsan Sâbis, Harp Hatıralarım: Birinci Dünya Harbi, Cilt: I, Nehir Yayınları, İstanbul, 1990, s. 230.

80- Gayrinizami kuvvetlere karşı harekât konusunda detaylı bilgi için bk. U.S. Marine Corps Field Manuel (FM) 90-8/MCRP 3-33A, Counterguerilla Operations, U.S.Government Printing Office, Washington, 1986, p. 1-1, 1-5.

81- Feridun Kandemir, Hatıraları ve Söyleyemedikleri ile Rauf Orbay, Sinan Matbaası, İstanbul, 1965, s. 80.

82- Ahmet Tetik, a.g.e., s. 270-290.

83- Mehmet Bilgin, Teşkilât-ı Mahsusa'nın Kafkasya Misyonu ve Operasyonları, Ötüken Neşriyat, İstanbul, 2018, s. 122. 
olunan kuvvete katılan çok sayıda mücahitle birlikte faaliyet gösterildiği anlaşılmaktadır. ${ }^{84}$ Bu telgrafın çekilmesinden yalnızca on gün sonra da Ömer Naci Bey müfrezesi Tebriz’e girmiş ve Ahraz'da petrol enerji hatlarını tahrip etmiştir. ${ }^{85}$ Yine Binbaşı Hüseyin Rauf Müfrezesi'nin İstanbul'dan yola çıktığı günlerde, Ruslara karşı faaliyet göstermek üzere Şuayb oğlu Ali Mürtez, Muhyiddin Bottay, Teymur Han, Hacı Hüseyin oğlu Nur Mehmet, Adapazarlı Cemal Bey'in İran’a gönderilmesi, Mart 1915'de ise Şerif Bey'in sabotajlarda bulunmak üzere Tahran’a gelmesi ve Tahran Sefiri Asım Bey ile irtibata geçmesi de Teşkilât-1 Mahsusa’nın bu bölgede faaliyette olduğunun göstergesidir. ${ }^{86}$

11 Kasım 1914 ilan edilen "Cihad-ı Mukaddes" ile İslam âleminin ortak düşmana karşı birlikte mücadele etmeye çağrılmasını ${ }^{87}$ ve bu vesileyle harp potansiyelinin artırılmaya çalışılmasını da bu kapsamda değerlendirmek gerekir. ${ }^{88}$ Cihad-1 Mukaddes beyannamesi ve psikolojik harbe yönelik diğer belgeler Farsça ve Arapça'ya tercüme ettirilerek uçaklar, casuslar ve diğer yöntemlerle İran, Hindistan, Kuzey Afrika, Orta Asya ve Kafkasyaya dağıtılmıştır. ${ }^{89}$ Yine başta İran ve Irak olmak üzere Müslüman topraklarında "her şeyden haber almak" maksadıyla "Seda-yı İslam" adında bir gazete kurulduğu, Sebilür Reşat, Volkan, İkdam, Sabah gibi gazetelerin psikolojik harp amacıyla kullanıldığg görülmektedir. ${ }^{90}$

Tüm bu gayretlere rağmen müfrezenin ilk teşkil amacı olan Afganistan üzerinden Hindistan'ı ayaklandırma gayesine ulaşılamaması, ardından yeni hedef olarak belirlenen İran'da ise kendisinden beklenileni tam anlamıyla verememesinin muhtelif gerekçeleri vardir.

Müfrezenin temel problemi "gizlilik" prensiplerine yeterince riayet edilmemiş olmasıdır. Niedermayer'in "gezici sirk" görüntüsü vermeye çalıştı̆̆ı ekibine ait malzemelerin Bükreş’ten yüklenmesi esnasında seyyar telsiz ekipmanlarının deşifre edilmesi ve bu görev için seçilen personelin İstanbul'da bulunduğu süre zarfındaki tedbirsiz davranışlarıyla bir nevi "gafil muhbirlik" etmeleri gizlilik ihlallerinden bazılarıdır. ${ }^{11}$ Zaten 1857 yılında Hindistan'da yaşanan başkaldırıdan ${ }^{92}$ aldıkları dersler nedeniyle temkinli davranan

84- Sadık Sarısaman, “Ömer Naci Bey Müfrezesi”, A.Ü. TİTE Atatürk Yolu Dergisi, Cilt: 4, Sayı: 16 (1995), s. 501.

85- Erdal İlter, Milli İstihbarat Teşkilatı Tarihçesi, Mi̇T Basımevi, Ankara, 2002, s. 9-10.

86- Çağdaş Yüksel, “Birinci Dünya Savaşı Sırasında İran’da Osmanlı-Rus Mücadelesinde Tahran Sefareti’nin Rolü”, Avrasya Sosyal ve Ekonomi Araştırmaları Dergisi (ASEAD), Cilt: 4, Sayı: 11 (2017), s. 289.

87- A.Ü. TİTE Arşivi, Klasör: 12, Gömlek: 40, Tarih: 10/1914.

88- Birinci Dünya Harbinde Türk Harbi..., Cilt: VI, s.145.

89- Sadık Sarısaman, Birinci Dünya Savaşı'nda Türk Cephelerinde Beyannamelerle Psikolojik Savaş, Genelkurmay Başkanlığı ATASE Yayınları, Ankara, 1999,s.18.

90- Mehmet Mert Çam, İran'da İstihbarat Savaşı: Birinci Dünya Savaşı'nda İran Cephesi'ndeki Psikolojik Harp Faaliyetleri, İlgi Kültür Sanat Yayıncılık, İstanbul, 2016, s. 100-102.

91- Sean McMeekin, a.g.e., s. 126-129.

92- İngiliz idaresine karşı 1857 y1lında Kanpur ve Lucknow başta olmak üzere geniş bir alanda yaşanan ve 11 binden fazla İngiliz ile sayısı net olarak bilinmemekle birlikte milyonlarla ifade edilen Hintli'nin ölmesine neden olan büyük bir isyan yaşanmıştır. Ancak lider kadrosunun yetersizliği, ulusal çapta halk desteğinden 
İngilizler, edindikleri istihbaratın ardından bir yandan fiziki engeller inşa ederken, ${ }^{93}$ diğer yandan da yoğun propaganda-beşinci kol faaliyetleriyle Hindu ve Müslümanlar arasındaki uçurumu daha da derinleştirmeyi başarmışlardır.

Müfrezenin karşılaştığı sorunlardan birdiğeri de teknik imkansızlıklar ve lojistik destek unsurlarının yetersizliğidir. Tahran Sefiri Asım Bey’in Hariciye Nezareti’ne (İstanbul) gönderdiği 16 Mart 1915 tarihli bir telgraf bu eksikliklerin tespiti açısından önemlidir. Asım Bey bahse konu telgrafta; Afganistan ile telgraf bağlantısının bulunmadığına dikkat çekmiş, bu bölgeye yönelik bir heyet teşkil edilebilse dahi buradaki faaliyetlerden yirmi günden evvel haber almanın mümkün olmadığından söz etmiş ve bir tanesi hafi olarak Tahran Sefarethanesi’nde bulundurulmak, diğeri de lüzumuna göre Afganistan’a gönderilmek üzere iki telgraf cihazı ile memûrin-i lazimenin bir an evvel gönderilmesini istemiştir. ${ }^{94}$ Konu hakkında Hariciye Nezareti tarafından 22 Mart 1915 tarihinde Harbiye Nezareti'ne gönderilen yazıda; tahsis edilmesi gerekecek cihaz sayısı, görevlendirilecek personel ve alınacak tedbirler konusunda tasarruf hakkının Harbiye Nezareti’ne ait olduğu belirtilmiş ve gelişmeler hakkında Tahran Sefiri Asım Bey'in bilgilendirilmesi istenmişse de, maliyet ve temin süresi gerekçe gösterilerek bahse konu istek karşılanmamıştır. ${ }^{95}$

Bu belgelerden hareketle Afganistan, dolayısıyla Hindistan’a yönelik muntazam bir heyet teşkil edilse ve bu heyet o bölgeye ulaşmayı başarsa dahi sağlıklı bir haberleşmenin sağlanamayacağı ve gelişmelerin yirmi gün gibi uzun bir gecikme sonrasında Türk tarafına ulaşabileceği çıkarımında bulunulabilir. Her ne kadar gayrinizami kuvvetlere konvansiyonel birliklere nazaran daha fazla inisiyatif kullanma yetkisi verilse de bu durum emir-komuta ilişkisinin kesintiye uğramasına ve personel, para, malzeme takviyesi konusunda zaafiyet yaşanmasına sebep olacaktır.

Diğer bir problem sahası da kontrol altına alınmaya çalışılan alan ile müfrezenin mevcudu arasındaki orantısızlıktır. Hüseyin Rauf Bey'in askeri gücüher tarafı düşmanla kaplı yüz seksen kilometrelik menzil hattı ve on beş kilometrelik bir muharebe hattını kontrole yeterli değildir ve bu anlamda Osmanlı Devleti tarafından da yeterince desteklenememiştir. Hüseyin Rauf Bey’in emrindeki ana kuvvetler, Mülazım-1 evvel Osman Bey (General Osman Tufan) komutasındaki yaklaşık 200 kişilik Bağdat YedekSubay Mektebi talebeleri ${ }^{96}$ ile yerel halktan oluşturulan birliklerdir. Bu kuvvetin önemli bir bölümünü oluşturan Iraklı gönüllü aşiret birliklerinin, hududa yakın olan İran aşiretleriyle olan akrabalık

yoksun olmaları, silah-teçhizat eksiklikleri, mücadelenin çok geniş bir coğrafyaya yayılması ve organizasyon bozukluğu gibi sebeplerle ayaklanma başarısız olmuştur. Daha önce bu çapta bir isyanla karşılaşmamış olan İngilizler, bu ayaklanmayı ancak Haziran-1858'de, kendilerine sadık olan Hintli askerlerin yardımıyla bastırabilmişler ve tecrübesizlik/hazırlıksızlığın sebep olduğu paniğin de etkisiyle karşılarına çıkan herkesi öldürmüşlerdir. Detaylı bilgi için bk. Hüseyin Günarslan, "1857 Hint İsyanı: Kanpur Katliamı ve Lucknow Mücadelesi”, Medeniyet ve Toplum Dergisi, Cilt: III, Say1: 1 (2019), s. 91-110.

93- Vahdet Keleşyılmaz, a.g.e., s. 109.

94- BOA, HR.SYS., D: 2407, G: 31-001, Tarih: 16.03.1915.

95- BOA, HR.SYS., D: 2407, G: 31-002 ve 006, Tarih: 22.03.1915.

96- A.Faik Hurşit Günday, Hayatım ve Hatıralarım, Çelikcilt Matbaası, İstanbul, 1969, s. 105-112. 
ilişkilerinin de etkisiyle devamlı surette firar etmeleri, onlardan yeterince istifade edilememesine neden olmuştur. ${ }^{97}$

Aşiretlerin bu tavırlarını ve önemli bir bölümünün İngiliz-Rus güdümünde hareket etmelerini halk desteğinin sağlanamamış olmasında aramak gerekir. Gayrinizami unsurların ihtiyaç duyduğu insan kaynağı havuzunu oluşturmaları, silah-teçhizat ve lojistik destek malzemeleri sağlamaları, düşman takibi durumunda gizlenme ve kamufle imkanı yaratmaları, haber alma ve istihbarat elemanı olarak kullanılmaları nedeniyle ${ }^{98}$ istisnasız olarak tüm modern gayrinizami harp teorisyenleri tarafından "gayrinizami harbin temel gereksinimi" ve "kritik faktör" olarak kabul edilen "halk desteği" konusunda genelde Osmanlı Devleti, özelde ise Hüseyin Rauf Bey Müfrezesi arzu edilen noktaya erişememiştir. ${ }^{99}$ Şii-Sünni ihtilafını bertaraf etmek ve Kürt aşiretleri kazanmak adına İran halkı ile İslam ortak paydasında buluşmak için büyük gayret gösterilmiş olmasına rağmen, İranlı Kürt aşiretlerden sınırlı sayıda katılım sağlanmış, ${ }^{100}$ İranlı Şii ve Türk gruplar Osmanlı Devleti ve Almanya yanında saf tutarken; Ermeni ve Asuriler İtilaf Devletleri yanlısı bir tutum sergilemişlerdir. ${ }^{101}$

97- Barış Metin, a.g.t., s. 54-56, 63.

98- Şahap Karapınar, “(Gerilla-Komando) Çete Savaşları”, Donanma Dergisi, İstanbul Deniz Matbaası, Cilt: 66, Say1: 404 (1953), s. 101.

99- Topyekûn harp kavramının yaratıcısı olarak kabul edilen Carl Von Clausewitz'e göre harbin, özellikle de gerilla harbinin en can alıcı özelliği “topyekûn” olmasıdır ve başarı için halkın tüm kesimlerinin silaha sarılması zorunludur. Vladimir İ.Lenin, harbin bir ülkenin bütün ekonomik ve örgütsel güçlerini sınadı̆̆ı, bu nedenle bir isyana toplumun bütün kesimlerinin katılması gerektiği kanaatindedir. Mao’ya göre gerilla harbinin en önemli unsurlarından biri halk desteğidir ve silah-teçhizat temininden de önemli bir husus olan halk desteği sağlanmadan gerillalar varlığını sürdüremez. Ho Chi Minh de Vietnam'da Fransız birliklerine karşı verdiği mücadelenin başarısının toplumun tüm kesimlerini kucaklamaya bağlı olduğunu bildiğinden ayrıştırıcı değil; birleştirici bir tavır sergilemiş, “daha çok dost ve daha az düşman kazanma” politikası gütmüştür. Fidel Castro ve Ernesto (Che) Guevara gibi tanınmış gerillaları yetiştiren General Alberto Bayo, geniş halk yığınlarının desteğinden yoksun bir başkaldırışın başarısız olacağı kanaatindedir. Ernesto (Che) Guevara da gayrinizami harbin başarısını uygulanacak taktiklerin bölge halkının hassasiyetlerine göre belirlenmesi ve onlarla koordineli olarak uygulanmasına bağlamaktadır. Uluslararası literatürde gayrinizami harp konusunda otorite olarak kabul edilen Otto Heilbrunn, gerillaların ancak halkın kendi taraflarında bulunduğu veya terör yaratarak kontrol altında tutulduğu yerlerde başarılı olabileceğini savunanlardandır. Rus sivil harbi esnasında gerilla kuvvetlerine komutanlık eden ve sonraları Sovyet istihbaratının en bilinen isimlerinden biri haline gelen General Alexander Orlov da halk desteği olmadan gerilla harbinin kazanılmasının mümkün olmadığını kanısındadır. Detaylı bilgi için bk. C.V.Clausewitz, Savaş Üzerine, Çev: H.Fahri Çeliker, Özne Yayınları, İstanbul, 1999, s. 446-451; Vladimir İ.Lenin, "Doğu Halklarının Kurtuluşu”, Marksizm ve Gerilla Savaşı, Der: William J.Pomeroy, Belge Yayınları, İstanbul, 1992, s. 129-134; Mao Tse-Tung, Selected Military Writings of Mao Tse-Tung, Foreign Language Press, Peking, 1963, p. 70; Robert C.Suggs, Brenda M.Wolak, "Mao's Three Stages: Factor Fantasy”, Military Review, Vol: XLVI (Nov. 1966), No: 11, p. 92-97; Mesut Uyar, Gerilla Savaşı, Yayımlanmamış Yüksek Lisans Tezi, İstanbul Üniversitesi, 1995, s. 84; Vo-Nguyen Giap, Halk Savaşı, Halk Ordusu, Çev: Muzaffer Ardos, Sol Yayınları-Başnur Matbaası, Ankara, 1968, s. 75-84; Alberto Bayo, Gerilla Nedir, Çev: Mekin Gönenç, Ant Yayınları, İstanbul, 1968, s. 20; Ernesto (Che) Guevara, Guerrilla Warfare, University of Nebraska Press, Newyork, 1998, p. 77-92; Otto Heilbrunn, Düşman Gerisinde Harp, Genelkurmay Basımevi, Ankara, 1974, s. 85; Alexander Orlov, İstihbarat ve Gerilla Harbi El Kitabı, Genelkurmay Basımevi, Ankara, 1964, s. 110-111. 100- Tuncay Öğün, “Osmanlı Basınında Cihad-1 Ekber: İran Örneği”, Türkiyat Mecmuası, Cilt: 28, Sayı: 1 (2018), s. 97-100.

101- Ervand Abrahamian, op.cit., p. 24-25; Süleyman Erkan, a.g.m., s. 99. 
Yine arşiv belgelerinden anlaşıldığı kadarıyla maddi sıkıntılarda hat safhadadır. Müfrezenin ana para kaynağını İstanbul'dan yola çıkarken Almanlar tarafından temin edilen atmış bin Osmanlı altını oluşturmaktadır. Almanlar ile yolların ayrılması sonrasında bu parayı kontrolü altına alan Hüseyin Rauf Bey bu meblağın önemli bir bölümünüörtülü faaliyetler için kullanmıştır. ${ }^{102}$ Bunun dışında İstanbul'dan istenilen ödeneğin ancak kısıtlı bir bölümünün gönderildiği ve bu gönderimin de zamana yayıldığı görülmektedir. ${ }^{103}$

Müfrezenin temel sorunlarından biri de iki farklı ülke personeli tarafından teşkil edilmiş olmasıdır.Emir-komutailişkisikesinçizgilerlebelirlenmemiş, aynırtakamaçdoğrultusunda güdülenmemiş, operasyon öncesinde harekât sahasına yönelik yeterince simülasyon yapılmamış bir ortamda başarı yakalanamayacağı gibi, çıkarların çatıştığı anda her ülke personelinin kendi milli çıkarları doğrultusunda tavır alması da kaçınılmazdır. Nitekim, I. Dünya Harbi’ne müttefik olarak girerek, bir nevi kader ortaklığ 1 yapan Almanlar ve Türkler bu görev sırasında yalnızca yollarını ayırmakla kalmamış, aleni veya örtülü olarak yekdiğerine zarar verecek hareketler içine de girmişlerdir. ${ }^{104}$

\section{SONUÇ}

Binbaşı Hüseyin Rauf (Orbay) Müfrezesi’nin ilk teşkil sebebi olan Afganistan üzerinden Hindistan'a ulaşma ve İngiltere'yi can evinden vurma amacını gerçekleştiremediği aşikardır. Ancak yaşanan fikir ayrılıkları neticesinde birleşik harekâta son verilerek, Türk ve Alman personelin müstakil hareket etmeye başlamasıyla birlikte Hüseyin Rauf Bey ve arkadaşlarının faaliyetleri yeni bir boyut kazanmış ve İran üzerine yoğunlaşılmıştır.

Yıllardır yaşanan siyasi istikrarsızlığa İngiltere, Rusya, Almanya gibi dönemin başat aktörlerinin verdiği nüfuz mücadelesinin de eklenmesiyle tam bir kaosun hâkim olduğu zorlu İran coğrafyasında Hüseyin Rauf Bey ve arkadaşları etkileri o an için yeterince

102- A.Faik Hurşit Günday, a.g.e., s. 105-112.

103- ATASE Arşivi, BDH Kataloğu, Klasör 7, Dosya 37A-013, 37A-013-1 ve 37A-013-3, Tarih: 08.03.133031.05.1331.

104- İran'da iki ülkenin yollarının ayrılmasından sonra Oscar von Niedermayer ve “German Lawrance” olarak anılan Wilhelm Wasmuss gibi Alman personelin, Ruslar tarafından kullanılan demiryolları ve köprülerin havaya uçurulması, İngiliz haberleşme hatlarının kesilmesi, İran' da banka soygunları yapılarak ihtilal için gerekli maddi desteğin sağlanması ve aşiretlerle (işbirliği halinde müttefiklik ilişkisi içinde oldukları) Türk kuvvetlerine karşı baskınlar düzenlenmesi gibi gayrinizami harp faaliyetleri içinde bulundukları görülmektedir. Bu yaklaşım, Sezen Kılıç’ın; “Türk-Alman ilişkilerinin iki yüzü vardır. Bunlardan birincisi, Almanların Türklere karşı resmi olarak takındığı dost yüz, ikincisi ise bilinçaltlarında yatan sömürgeci yüzdür.” ifadelerini desteklemektedir. Ayrıca literatürde Alman Erkân-1 Harbiye Reisi Moltke'den Profesör Hasse'ye kadar Anadolu ve Orta doğu'yu gelecekteki Alman dominyoları olarak gördükleri ve bu doğrultuda hareket ettikleri yönünde yaygın bir görüş de hâkimdir. Detaylı bilgi için bk. Sean McMeekin, The Ottoman End Game: War, Revolution, and The Making of The Modern Middle East (1908-1923), Penguin Press, New York, 2015, p. 294-296; Sezen K1lıç, Türk-Alman İlişkileri ve Türkiye'deki Alman Okullarl [1852'den 1945'e Kadar], Atatürk Araştırma Merkezi Yayınları, Ankara, 2005, s. 2-177; Vladimir Jabotinsky, Türkiye ve Savaş, Çev: Zehra Tapunç, Gerekli Kitap, İstanbul, 2007, s. 34. 
anlaşılamayan önemli bir misyon yüklenmişlerdir. Nitekim bu girişimin meyvelerinin sonraki günlerde toplandığının en somut göstergelerinden biri, Eylül-1914'te Hüseyin Rauf Bey ile birlikte yola çıkan ve Haziran 1915’te İran Ataşemiliteri olarak görevlendirilen Teşkilât-1 Mahsusa’nın önemli isimlerinden Ömer Fevzi Bey tarafindan 1917 yılında hazırlanan rapordur. Bahse konu raporda; Osmanlı aleyhine tahrik için yapılan vaatlere ve hatta Bağdat, Kerbela, Necef gibi önemli toprakların mükâfat olarak verileceğinin taahhüt edilmesine rağmen İran'ın bunlara tam’ etmediği, her türlü tehdide göğüs gererek Osmanlı harekât tarzına uygun bir tutum sergilediği belirtilmiştir. ${ }^{105}$

Şayet bu tür gayrinizami harp faaliyetlerine başvurularak, İtilaf Devletleri'nin önemli miktardaki askeri gücü ve istihbarat unsurları bu coğrafyada meşgul edilmemiş olsaydı, I. Dünya Harbi’nin Osmanlı Devleti için çok daha çabuk biteceği ve daha büyük bir felaketle sonuçlanacağına da şüphe yoktur. 


\section{KAYNAKÇA}

A.Ü. TİTE Arşivi, Klasör: 12, Gömlek: 40, Tarih: 10/1914.

BOA, HR.SYS., D. 2316, G: 14, Tarih: 25.10.1914.

BOA, HR.SYS., D: 2340, G: 41-001-003, Tarih: 20.07.1917.

BOA, HR.SYS., D: 2340, G: 41-001-003 ve 004, Tarih: 20.07.1917.

BOA, HR.SYS., D: 2407, G: 31, Tarih: 16.03.1915.

BOA, HR.SYS., D: 2407, G: 31-001, Tarih: 16.03.1915.

BOA, HR.SYS., D: 2407, G: 31-002 ve 006, Tarih: 22.03.1915.

BDH Koleksiyonu, Klasör 7, Dosya 37A-004, Tarih: 08.03.1330-31.05.1331.

BDH Koleksiyonu, Klasör 7, Dosya 37A-005-1, Tarih: 08.03.1330-31.05.1331.

BDH Koleksiyonu, Klasör 7, Dosya 37A-007-01, Tarih: 08.03.1330-31.05.1331.

BDH Koleksiyonu, Klasör 7, Dosya 37A-007-02, Tarih: 08.03.1330-31.05.1331.

BDH Koleksiyonu, Klasör 7, Dosya 37A-008-1, Tarih: 08.03.1330-31.05.1331.

BDH Koleksiyonu, Klasör 7, Dosya 37A-009, Tarih: 08.03.1330-31.05.1331.

BDH Koleksiyonu, Klasör 7, Dosya 37A-009-1, Tarih: 08.03.1330-31.05.1331.

BDH Koleksiyonu, Klasör 7, Dosya 37A-009-2, Tarih: 08.03.1330-31.05.1331.

BDH Koleksiyonu, Klasör 7, Dosya 37A-009-3, Tarih: 08.03.1330-31.05.1331.

BDH Koleksiyonu, Klasör 7, Dosya 37A-013, Tarih: 08.03.1330-31.05.1331.

BDH Koleksiyonu, Klasör 7, Dosya 37A-013-1, Tarih: 08.03.1330-31.05.1331.

BDH Koleksiyonu, Klasör 7, Dosya 37A-013-3, Tarih: 08.03.1330-31.05.1331.

BDH Koleksiyonu, Klasör 7, Dosya 37A-013-5, Tarih: 08.03.1330-31.05.1331.

BDH Koleksiyonu, Klasör 7, Dosya 37A-016-025, Tarih: 08.03.1330-31.05.1331.

BDH Koleksiyonu, Klasör 7, Dosya 37A-016-030, Tarih: 08.03.1330-31.05.1331. 
BDH Koleksiyonu, Klasör 7, Dosya 37A-017, Tarih: 08.03.1330-31.05.1331.

BDH Koleksiyonu, Klasör 7, Dosya 37A-017-5, Tarih: 08.03.1330-31.05.1331.

BDH Koleksiyonu, Klasör 7, Dosya 37A-017-6, Tarih: 08.03.1330-31.05.1331.

BDH Koleksiyonu, Klasör 7, Dosya 37A-024-1, Tarih: 08.03.1330-31.05.1331.

BDH Koleksiyonu, Klasör 7, Dosya 37A-030-1, Tarih: 08.03.1330-31.05.1331.

BDH Koleksiyonu, Klasör 3603, Dosya No: 3-2-8, Tarih: 01.12.30-23.12.30.

BDH Koleksiyonu, Klasör 3610, Dosya 30, Tarih: 00.07.1330-00.11.1331.

İBB Atatürk Kitaplığı Arşivi, Bel_Mtf_025636.

, "Birinci Dünya Savaşı Sırasında İran'da Osmanlı-Rus Mücadelesinde Tahran Sefareti'nin Rolü”, Avrasya Sosyal ve Ekonomi Araştırmaları Dergisi (ASEAD), Cilt: 4, Sayı: 11 (2017), s. 285-293.

, "Ömer Naci Bey Müfrezesi”, A.Ü. TİTE Atatürk Yolu Dergisi, Cilt: 4, Sayı: 16 (1995), s. 501-513.

The Ottoman End Game: War, Revolution, and The Making of The Modern Middle East (1908-1923), Penguin Press, New York, 2015.

ABRAHAMIAN, Ervand, "Factionalism in İran: Political Groups in the 14th Parliament (1944-1946)", Middle Eastren Studies, Vol: 14, No: 1 (1978), p. 22-55.

ADAMEC, Ludwig W., Afghanistan (1900-1923): A Diplomatic History, University of Califonia Press, Los Angeles, 1967.

ARSLAN, Emir Şekip, Bir Arap Aydınının Gözüyle Osmanlı Tarihi ve 1. Dünya Savaşı Anıları, Çev: Selda Meydan, Ahmet Meydan, Çatı Kitapları, İstanbul, 2005.

ATUK, M. Volkan, “İttihat ve Terakki Cemiyeti’nin İran Politikası”, Belleten, Cilt: 83, Say1: 296 (2019), s. 261-288.

Başlangıcından Bugüne Dünya Casusluk Tarihi, Cilt: I, Artel Yayınları, İstanbul, 1974.

BAYO, Alberto, Gerilla Nedir, Çev: Mekin Gönenç, Ant Yayınları, İstanbul, 1968.

BİLGIN, Mehmet, Teşkilât-ı Mahsusa’nın Kafkasya Misyonu ve Operasyonları, Ötüken Neşriyat, İstanbul, 2018. 
Birinci Dünya Harbinde Türk Harbi: Irak-İran Cephesi (1914-1918), Cilt: III, 1'nci Kısım, Genelkurmay Basımevi, Ankara, 1979.

Birinci Dünya Savaşına Katılan Alay ve Daha Üst Kademedeki Komutanların Biyografileri, Yay.Haz: Hülya Toker, Nurcan Aslan, Cilt: III, Genelkurmay Basımevi, Ankara, 2009.

British Documents on Foreign Affairs: Reports and Papers from the Foreign Office Confidental Print, Series: B (Persia, Britain and Russia 1907-1914).

CLAUSEWITZ, C.V., Savaş Üzerine, Çev: H.Fahri Çeliker, Özne Yayınları, İstanbul, 1999.

ÇAM, Mehmet Mert, İran'da İstihbarat Savaşı: Birinci Dünya Savaşı’nda İran Cephesi’ndeki Psikolojik Harp Faaliyetleri, İlgi Kültür Sanat Yayınc1lık, İstanbul, 2016.

ÇOLAK, Fatih, Alman Arşiv Belgelerine Göre Almanya’nın Türkistan Siyaseti (1910-1920 Yilları Arasında), Yayımlanmış Doktora Tezi, Necmettin Erbakan Üniversitesi, 2019.

ÇOLAK, Mustafa, Alman İmparatorluğu’nun Doğu Siyaseti Çerçevesinde Kafkasya Politikası (1914-1918), Türk Tarih Kurumu Yayınları, Ankara, 2006.

Department of Defence (DoD) Joint Publication (JP) 1-02, Dictionary of Military and Associated Terms, Joint Chiefs of Staff, USA, 2001.

DİNÇ, Mehmet Emin, Kûtü'l Amare’nin Muzaffer Komutanı Halil Kut Paşa, Kronik Kitap, İstanbul, 2017.

ERKAN, Hamza Osman, Bir Avuç Kahraman, İnkılâp Kitabevi, İstanbul, 1946.

ERKAN, Süleyman, “İran’a Yabancı Ülke Müdahaleleri (1907-1921)”, Akademik ORTA DOĞU Dergisi, Cilt: 5, Say1: 1 (2010), s. 91-116.

ESATLI, Mustafa Ragıp, İttihat ve Terakki, Hürriyet Yayınları, İstanbul, 1956.

EYMÜR, Mehmet, Analiz: “Bir MİT Mensubunun Anıları”, Elif Kitabevi, İstanbul, 2005.

Geçmişten Günümüze Türk-Afgan İlişkileri, Genelkurmay Başkanlığı ATASE Yayınları, Ankara, 2009.

GIAP, Vo-Nguyen, Halk Savaşı, Halk Ordusu, Çev: Muzaffer Ardos, Sol Yayınları-Başnur Matbaası, Ankara, 1968.

GÖRGÜLÜ, İsmet, On Yillık Harbin Kadrosu, Türk Tarih Kurumu Yayınları, Ankara, 1993.

GUEVARA, Ernesto (Che), Guerrilla Warfare, University of Nebraska Press, Newyork, 1998. 
GÜNARSLAN, Hüseyin, “1857 Hint İsyanı: Kanpur Katliamı ve Lucknow Mücadelesi”, Medeniyet ve Toplum Dergisi, Cilt: III, Sayı: 1 (2019), s. 91-110.

GÜNDAY, A.Faik Hurşit, Hayatım ve Hatıralarım, Çelikcilt Matbaası, İstanbul, 1969.

Halil Paşa: İttihat ve Terakki'den Cumhuriyet'e Bitmeyen Savaş-Kütûlamare Kahramanı Halil Paşa’nın Anıları, Haz: M.Taylan Sorgun, Yaylacık Matbaası, İstanbul, 1972.

HEILBRUNN, Otto, Düşman Gerisinde Harp, Genelkurmay Basımevi, Ankara, 1974.

HOPKIRK, Peter, İstanbul'un Doğusunda Bitmeyen Oyun, Çev: Mehmet Harmanc1, Sabah Kitapları, İstanbul, 1995.

İLTER, Erdal, Milli İstihbarat Teşkilatı Tarihçesi, MİT Basımevi, Ankara, 2002.

İmparatorluk Döneminde Türk-Alman İlişkileri: Goltz Paşa’nın Hatıratı, Haz: Faruk Yilmaz, Poyraz Ofset, Ankara, 2004.

JABOTINSKY, Vladimir, Türkiye ve Savaş, Çev: Zehra Tapunç, Gerekli Kitap, İstanbul, 2007.

KANDEMİR, Feridun, Hatıraları ve Söyleyemedikleri ile Rauf Orbay, Sinan Matbaası, İstanbul, 1965.

KARABEKİR, Kâzım, Gizli Harp: İstihbarat, Yay.Haz: Emrullah Tekin, Kamer Yayınları, İstanbul, 1998.

KARAPINAR, Şahap, “(Gerilla-Komando) Çete Savaşları”, Donanma Dergisi, İstanbul Deniz Matbaas1, Cilt: 66, Sayı: 404 (1953), s. 98-108.

KELEŞYILMAZ, Vahdet, Teşkilât-ı Mahsusa'nın Hindistan Misyonu (1914-1918), Atatürk Araştırma Merkezi Yayınları, Ankara, 1999.

KILIÇ, Selami, "Birinci Dünya Savaşına Uzanan Süreçte Türk-Alman Yakınlaşması”, 1914'den 2014'e 100'üncü Yilında Birinci Dünya Savaşı’n Anlamak, Harp Akademileri Basımevi, İstanbul, 2014, s. 91-155.

KILIÇ, Sezen, Türk-Alman İlişkileri ve Türkiye'deki Alman Okulları [1852'den 1945'e Kadar], Atatürk Araştırma Merkezi Yayınları, Ankara, 2005.

KON, Kadir, "Almanyảnın İslam Stratejisi Mimarlarından Max von Oppenheim ve Bu Konudaki Üç Memorandumu”, Tarih Dergisi, Sayı: 53 (2012), s. 211-252.

KON, Kadir,Birinci Dünya Savaşı'nda Almanya'daki Müslüman Esir Kampları (19141918), Yayımlanmamış Yüksek Lisans Tezi, Marmara Üniversitesi, 2011. 
KURAT, Akdes Nimet, Türkiye ve Rusya: XVII. Yüzyıl Sonundan Kurtuluş Savaşına Kadar Türk-Rus İlişkileri (1798-1919), Türk Tarih Kurumu Yayınları, Ankara, 2011.

KURŞUN,Zekeriya, Basra Körfezinde Osmanlı-İngiliz Çekişmesi: Katar'da Osmanlılar (1871-1916), Türk Tarih Kurumu Yayınları, Ankara, 2004.

KURTCEPHE, İsrafil; BALCIOĞLU, Mustafa, "Birinci Dünya Savaşı Başlarında Romantik Bir Türk-Alman Projesi-Rauf Bey Müfrezesi”, Osmanlı Tarihi Araştırma ve Uygulama Merkezi (OTAM) Dergisi, Sayı: 3 (1992), s. 247-269.

LENİN, Vladimir İ., “Doğu Halklarının Kurtuluşu”,Marksizm ve Gerilla Savaşı, Der: William J.Pomeroy, Belge Yayınları, İstanbul, 1992, s. 129-134.

LEVENT, Zeynel, Kuva-yı Milliye’den Teşkilât-ı Mahsusa'ya Gayrinizami Harp, Yayımlanmamış Doktora Tezi, Ankara Üniversitesi, 2019.

McMEEKİN, Sean, Berlin-Bağdat Demiryolu: Almanya’nın Doğu Hakimiyeti Mücadelesi ve Osmanl İmparatorluğu (1898-1918), Çev: Azize F.Çakır, Picus Yayıncılık, İstanbul, 2012.

Mehmet Kenan, Büyük Harpte İran Cephesi, (Osmanlıca Metin), Cilt: 2, Büyük Erkân-1 Harbiye Reisliği Ankara Matbaası, Ankara, 1928.

METİN, Barış, Birinci Dünya Savaşı̇nda İran Coğrafyasında Etnik, Dini ve Siyasi Nüfuz Mücadeleleri, Yayımlanmış Doktora Tezi, Ankara Üniversitesi, 2007.

Muhtasar İran ve Ordusu, Büyük Erkânıharbiye Matbaası, Ankara, 1930.

MÜHLMANN, Carl, İmparatorluğun Sonu 1914: Osmanlı Savaşa Neden ve Nasıl Girdi?, Çev: Kadir Kon, TİMAŞ Yayınları, İstanbul, 2009.

ORBAY, Rauf, Cehennem Değirmeni: Siyasi Hatıralarım, Emre Yayınları, İstanbul, 1993.

ORLOV, Alexander, İstihbarat ve Gerilla Harbi El Kitabı, Genelkurmay Basımevi, Ankara, 1964.

ÖĞÜN, Tuncay, “Osmanlı Basınında Cihad-ı Ekber: İran Örneği”, Türkiyat Mecmuası, Cilt: 28, Sayı: 1 (2018), s. 91-114.

ÖKE, Mim Kemal, Ömer Fevzi Mardin: Gazi ve Sufi, İrfan Yayımcılık, İstanbul, 2009.

POMIANKOWISKI, Joseph, Osmanlı İmparatorluğu’nun Çöküşü: 1914-1918 I. Dünya Savaşı, Çev: Kemal Turan, Kayıhan Yayınları, İstanbul, 1990.

SÂBİS, Ali İhsan, Harp Hatıralarım: Birinci Dünya Harbi, Cilt: I, II, Nehir Yayınları, 
İstanbul, 1990.

SAFİ, Polat, The Ottoman Special Organization-Teşkilât-ı Mahsusa: An Inquiry into its Operational and Administrative Characteristics, Yayımlanmamış Doktora Tezi, İhsan Doğramacı Bilkent Üniversitesi, 2012.

SANDERS, Liman von, Fünf Jahre Türkei (Mit zahlreichen Textskizzen und drei katren beliagen), Verlag Von August Scherl, Berlin, 1920.

SARAY, Mehmet, Afganistan ve Türkler, ASAM, Ankara, 2002.

SARISAMAN, Sadık, "Birinci Dünya Savaşı'nda Salarüddevle Olayı”, Atatürk Üniversitesi Türkiyat Araştırmaları Enstitüsü Dergisi, Sayı: 2 (2010), s. 149-153.

SARISAMAN, Sadık, Birinci Dünya Savaşı'nda Türk Cephelerinde Beyannamelerle Psikolojik Savaş, Genelkurmay Başkanlığı ATASE Yayınları, Ankara, 1999.

SUGGS, Robert C.; WOLAK, Brenda M., "Mao's Three Stages: Factor Fantasy", Military Review, Vol: XLVI (Nov. 1966), No: 11, p. 92-97.

ŞEHİTOĞLU, Mustafa; DOĞANAY, Rahmi, "İran Kaynaklarına Göre Nazi Döneminde Almanların İran'daki Casusluk ve Propaganda Faaliyetleri”, Fırat Üniversitesi Sosyal Bilimler Dergisi, Cilt: 29, Say1: 1 (2019), s. 449-465.

TETIKK, Ahmet, Teşkilat-ı Mahsusa (Umûr-ı Şarkıyye Dairesi) Tarihi (1914-1916), Cilt: I, Türkiye İş Bankası Kültür Yayınları, İstanbul, 2014.

TEZER, Şükrü, Atatürk'ün Hatıra Defteri, Türk Tarih Kurumu Yayınları, Ankara, 1995.

TOWNSHEND, Charles V.F., Mezopotamya Seferim: Kurna, Kûtülamare ve Selmanıpâk Muharebeleri, Çev: Gürol Koca, Türkiye İş Bankası Kültür Yayınları, İstanbul, 2012.

TSE-TUNG, Mao, Selected Military Writings of Mao Tse-Tung, Foreign Language Press, Peking, 1963.

TUNAYA, Tarık Zafer, Türkiye'de Siyasal Partiler: İttihat ve Terakki, Bir Çağın, Bir Kuşağın, Bir Partinin Tarihi, Cilt: 3, İletişim Yayınları, İstanbul, 2015.

U.S. Marine Corps Field Manuel (FM) 90-8/MCRP 3-33A, Counterguerilla Operations, U.S. Government Printing Office, Washington, 1986.

UYAR, Mesut, Gerilla Savaşı, Yayımlanmamış Yüksek Lisans Tezi, İstanbul Üniversitesi, 1995.

YAMAUCHİ, Masayuki, Hoşnut Olamamış Adam-Enver Paşa Türkiye’den Türkistan’a, 
Bağlam Yayınları, İstanbul, 1995.

YÜKSEL, Çağdaş, “Birinci Dünya Savaşı’nda Ataşemiliter Ömer Fevzi Bey’in İran'daki Faaliyetleri”, Ulakbilge Sosyal Bilimler Dergisi, Cilt: VI, Sayı: 30 (2018), s. $1549-1556$. 


\section{EKLER}

EK-1: Hamidiye Kahramanı (Süvarisi) Hüseyin Rauf (Orbay) Bey, Teşkilât-1 Mahsusa mensuplarından Ömer Fevzi (Mardin) Bey’le bir arada, İBB Atatürk Kitaplığı Arşivi, Bel_ Mtf_025636.

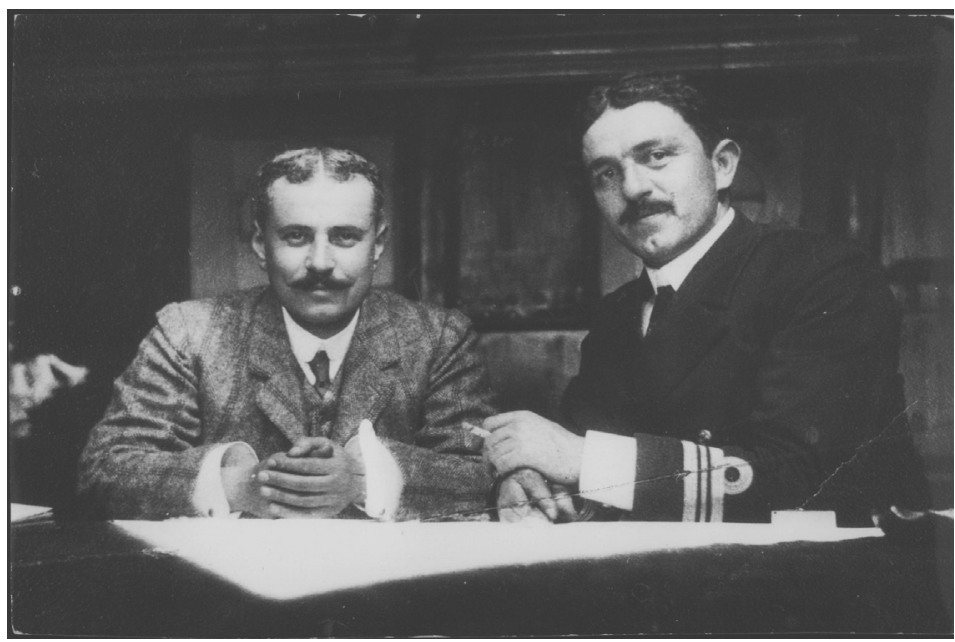

EK-2: Cihad-1 Mukaddes'e dair fetvanın Fatih Camii’nde okunması, A.Ü. TİTE Arşivi, Klasör: 12, Gömlek: 40, Tarih: 1914.

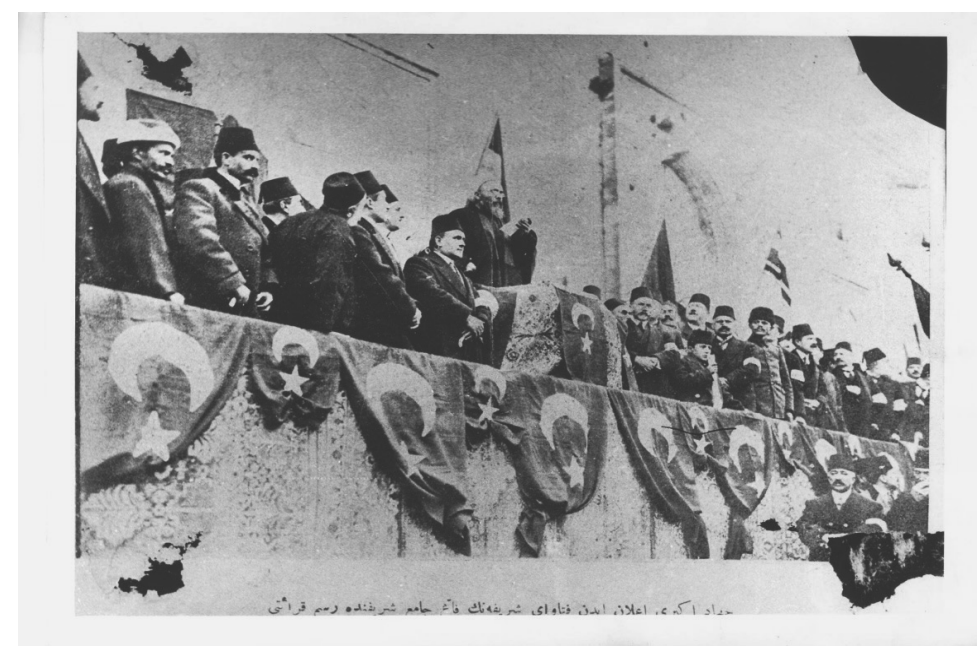

